\title{
Biomineralization of Carbonate Minerals Induced by Halophilic Chromohalobacter israelensis in High Salt Concentration: Implications for Natural Environments
}

\author{
Zuozhen Han ${ }^{1,2, *}$, Dan Li ${ }^{1}$, HuaXiao Yan ${ }^{2,3, *}$, Peiyuan Li ${ }^{1}$ \\ 1 Shandong Provincial Key Laboratory of Depositional Mineralization and Sedimentary minerals, College of \\ Earth Science and Engineering, 266590 Qingdao, China \\ 2 Key Laboratory of Marine Geology and Environment, Chinese Academy of Sciences, 266071 Qingdao, \\ China \\ 3 Department of Bioengineering, College of Chemical and Environmental Engineering, Shandong University \\ of Science and Technology, 266590 Qingdao, China \\ * Correspondence: Zuozhen Han: hanzuozhen65@126.com. \\ Huaxiao Yan: 15954804511@163.com \\ ** Zuozhen Han, Dan Li and Huaxiao Yan contributed equally to this paper and were considered as co-first \\ authors.
}

\begin{abstract}
High salt environment was widespread in modern and geological record, and sedimentation induced by microbes in these systems was an important part of sedimentary minerals and rocks. The mechanism of microbiologically induced carbonate precipitation has not been solved thoroughly although numerous scholars and experts have made specifically research of the problems with respect to minerals induced by bacteria. The study of carbonate minerals induced by Halophilic bacteria has aroused wide concern. The present study was aim to investigate the characterization and process of biomineralization in the high salt system, a Halophilic bacterium, Chromohalobacter israelensis LD532 strain (Genbank: KX766026), which isolated from Yinjiashan Saltern of China, was selected as an object to induce carbonate minerals. Carbonate minerals induced by LD532 were investigated in several comparative experimental sets with $\mathrm{Mg}$ resources of magnesium sulfate and magnesium chloride. Magnesium calcite and aragonite were induced by LD532 bacteria while these minerals were not in the control group. The mineral phases, micromorphologies, and crystal structures were analyzed using X-ray powder diffraction, scanning electron microscope, and energy dispersive $\mathrm{X}$-ray detector. Carbonic anhydrase and urease secreted by strain LD532 through metabolism promoted the $\mathrm{pH}$ values of the liquid medium and the process of carbonate precipitation. Further study proved that the nucleation sites of partial carbonate nucleus were located on the extracellular polymeric substance and the membrane of intracellular vesicles of LD532 bacteria by high resolution transmission electron microscopy, energy dispersive $\mathrm{X}$-ray detector and ultrathin slices analysis, which provided favorable conditions for the growth of carbonate mineral crystals. The morphology and composition of minerals formed in $\mathrm{MgSO}_{4}$ and $\mathrm{MgCl}_{2}$ solution have significant differences, indicating that different sources of $\mathrm{Mg}^{2+}$ could also affect the physiological and biochemical activities of microorganisms and then affect the mineral deposition. The accomplished study is of certain interest for interpretation of the carbonates biomineraliazation in natural salt environment, and has a certain reference value in understand of the sedimentary carbonates in ancient marine environment like evaporated tidal flat.
\end{abstract}

Keywords: Biomineralization; Halophilic bacteria; Precipitation; Carbonate minerals; Mg/Ca ratios; Nucleation sites 


\section{Introduction}

Carbonate minerals are widely distributed in the earth's crust and play an important role in the study of early diagenesis of marine sediments, calcification and the formation of cavernous chemical deposits [1]. In recent decades, many microbial fossils have been discovered in biolith, such as cyanobacteria, which confirmed that microbes were closely associated with the diagenesis of minerals. A large number of researchers have studied the ability of bacteria to precipitate minerals in the natural environment and laboratory based on previous research findings of the biolith such as stromatolite, oncolite, dendrite, and thrombolite [2-10]. Therefore, the role of microorganisms in the precipitation of a wide variety of carbonates has been generally acknowledged in recent years [11]. Interaction between microorganisms and minerals is a kind of geological action occurs widely in the natural environment, mineral dissolution and precipitation are almost inseparable from the role of microorganisms. Microbial mineralization can be traced back to the distant geological age - the formation of the Precambrian large-scale stromatolites and iron-rich construction, therefore, the carbonate precipitation induced by different species of bacteria was a vastly common event in natural environment [5]. The chemical changes of seawater aragonite induced by a bloom-forming filamentous diazotroph Trichodesmium under different phosphorus $(\mathrm{P})$ availability were monitored [12]. The morphology and mineralogy of carbonate minerals can be influenced by sulfate reducing bacteria which can produce copious amounts of the extracellular polymeric substances (EPS) and also increase the alkalinity by sulfate reduction and organic acids consumption [13]. Many researchers have studied the formation of calcite crystals by EPS secreted by Bacillus firmus and Bacillus sphaericus and found that the shape of the crystals depends on the fractions utilized [14].

In addition, the precipitation mechanisms of minerals have been further studied in the process of biomineralization. Some researchers have believed that bacteria can induce the formation of different types of carbonate as long as the conditions are right [15]. The precipitation of carbonates and other types of minerals by biomineralization is caused by the participation of specific macromolecules originated from bacteria in the culture medium [16]. Urease and carbonic anhydrase activity play an important role in microbiologically induced carbonate precipitation $[17,18]$. The mineralization mechanism of Bacillus has also been studied in the process of carbonate calcification [19]. However, in the formation process of microbial carbonates, there are still some controversies surrounding what specific role the different bacteria play in many cases $[2,20,21]$, and the optimal conditions for biomineralization are needed to explore [7].

Researchers have believed that the composition and ionic concentration of the solution have great influence on the mineral precipitation in geological environment, and have proved that acicular high- $\mathrm{Mg}$ calcite or aragonite can be produced in high $\mathrm{Mg} / \mathrm{Ca}$ ratio seawater or high salinity lakes [22]. In the formation of carbonate rocks, especially dolomite, $\mathrm{Mg}$ element has been involved in almost all the geochemical processes [23]. Calcite mineralization can be controlled by the $\mathrm{Mg} / \mathrm{Ca}$ ratios in seawater [24]. $\mathrm{Ca}, \mathrm{Mg}$ and $\mathrm{Mg} / \mathrm{Ca}$ ratios have an effect on the precipitation of $\mathrm{Mg}$-rich carbonate [25]. $\mathrm{Mg}^{2+}$ has some influence on the structure of monohydrocalcite in the formation process [26].

In recent years, the carbonate precipitation induced by halophilic bacteria has been a hot spot issue. Moderately halophilic bacteria are those that can grow optimally at the salt concentrations from $3 \%$ to $15 \%(\mathrm{w} / \mathrm{v})$ in their environment. Halophiles can survive in the high-salt condition due to their special cellular structure and metabolic mechanism. In previous studies, some scholars have induced different minerals using halophilic bacteria in different conditions. A moderately halophilic bacterium belonged to Chromohalobacter marismortui, which was isolated from the Dead Sea in 1940 by Elazari Volcani were described [27], and the precipitation of minerals induced by Chromohalobacter marismortui for the first time were studied [7]. At the different salt concentrations and incubation conditions, the carbonate precipitation induced by Halomonas Mónica were studied and observed the mineralogy of minerals $[5,28]$. The mechanism of mineralization induced by halophilic bacteria has also been studied by a number of researchers. The cellular envelope of bacterium was used as a nucleation site in the process of carbonate precipitation $[5-8,10,25]$. The 
EPS and the cell walls were defined as the nucleation sites [29]. Meanwhile, carbonic anhydrase activity was related to the formation of minerals [28]. Based on the above research, it can be seen that the mechanism of microbiologically induced carbonate precipitation has not been solved thoroughly although numerous scholars and experts have made many specific research of the problems with respect to minerals induced by bacteria, therefore, the mechanism of biomineralization is still needed to explore in depth.

In this paper, the carbonate precipitation induced by kind of bacterium, Chromohalobacter israelensis LD532 bacterium isolated from Yinjiashan Saltern in China, was studied at high salt $(\mathrm{NaCl})$ concentrations, $\mathrm{Mg} / \mathrm{Ca}$ ratios $\left(0,2,4,6,8\right.$, and 10) and $\mathrm{Mg}^{2+}$ sources. The experimental groups were inoculated with $1 \%$ of $C$. israelensis LD532 bacterial liquid seed and the control groups were inoculated with the same volume of sterile distilled water. X-ray diffraction (XRD), scanning electron microscope (SEM) and energy dispersive X-ray detector (EDS) were used to study the mineralogy and morphology of the carbonate crystals induced by C. israelensis LD532 bacteria. Organic functional group originated form LD532 bacteria in carbonate minerals were observed by fourier transform infrared spectroscopy (FTIR). High-resolution transmission electron microscopy (HRTEM), selected area electron diffraction (SAED) and energy dispersive spectrometer (EDS) were used to analyze the morphology and the elemental composition of mineral crystals on the EPS of $C$. israelensis LD532 bacteria. To further determine the nucleation sites of carbonate minerals, the ultra-thin slices of $C$. israelensis $\mathrm{LD} 532$ bacteria in $\mathrm{MgSO}_{4}$ and $\mathrm{MgCl}_{2}$ culture medium were prepared and observed by TEM. Carbonic anhydrase (CA) and urease were also investigated in order to further explore the mechanism of microbial induced carbonate minerals. Through the study of carbonates biomineralization process, it provides the reference for the formation mechanism of carbonate minerals in the geological record, is beneficial to understand microbial mineralization in the natural environments and the laboratory environments, also helps to explain the origin of ancient carbonate sedimentary environment.

\section{Materials and Methods}

\subsection{Culture media}

Liquid enrichment culture medium with the following composition was used: ( $\mathrm{g} \mathrm{L}^{-1}$ deionized water) beef extract 5.0, tryptone 10.0, $\mathrm{NaCl} 150$, and the $\mathrm{pH} 7.2$. The solid medium was added $20 \mathrm{~g}$ $\mathrm{L}^{-1}$ agar based on the above liquid medium. The above culture medium was also used to isolate and purify the halophilic bacteria.

\subsection{Isolation and identification of bacterial LD532}

LD532 bacterium was isolated from water samples collected from Yinjiashan saltern $\left(35^{\circ} 48^{\prime} \mathrm{N}\right.$, $\left.119^{\circ} 55^{\prime} \mathrm{E}\right)$, Qingdao, China. The water samples were put into the liquid enrichment medium by $1 \%$ of inoculation volume and incubated at $130 \mathrm{rpm}$ and $30{ }^{\circ} \mathrm{C}$ in a constant temperature shaker (HZQ-F160, Harbin Donglian Electronic Technology Development Co., Ltd, China). The medium turned turbid after 2 days of culture, indicating that there were several dominant types of halophilic bacteria present. The change in transparency is mainly attributable to the physiological and biochemical activities of halophilic bacteria. The turbid enrichment medium was diluted 1,000 fold using sterile distilled water and the diluent was coated evenly on the solid medium for further isolation and purification. All the bacterial cultures were incubated at $30{ }^{\circ} \mathrm{C}$ in the electrothermal constant temperature incubator (DHP-9050B, Shanghai Langgan Laboratory equipment co., LTD, China) until single colonies could be observed by the naked eyes. A single bacterial colony was then selected to further purify for 3 times. The pure strain named LD532 was obtained and then identified by physiological and biochemical identification and 16S rDNA identification [30].

Bacterial genomic DNA was extracted with the improved cetyltrimethylammonium bromide (CTAB) method [31], and used as the template for PCR. The 16S rDNA gene sequences were amplified with universal primers 27F (5'-agagtttgatcatggctcag-3') and 1492R (5'tacggttaccttgttacgactt-3') [32]. The PCR products were then analyzed via agarose gel electrophoresis. 
The gene fragments about $1500 \mathrm{bp}$ long in the agarose gel were the expected products. The PCR products were sequenced by Shanghai Sangon Biotech Co., Ltd. The complete DNA sequence was obtained through fragment assembly using DNAMAN 8.0 software. Subsequently, a nucleotide homology comparison was carried out using Basic Local Alignment Search Tool (BLAST) software. The phylogenetic tree of LD532 was constructed using MEGA 5.0 software with a neighbor-joining method [33]. The 16S rDNA sequence of $C$. israelensis LD532 has been deposited in GenBank under accession number KX766026.

\subsection{Morphology of C. israelensis LD532 Bacteria by TEM}

After 10 days of incubation at $30^{\circ} \mathrm{C}$, a single colony with a diameter of about $5 \mathrm{~mm}$ on the solid medium was transferred to a $1.5 \mathrm{~mL}$ centrifuge tube and diluted with $200 \mu \mathrm{L}$ of distilled water. The above dilution was sucked up and dripped onto a copper grid, and then analyzed by TEM (JEM-2100, Japan Electronics Company, JEOL, Japan) after natural drying.

\subsection{Growth of $\mathrm{C}$. israelensis LD532 bacteria at Different $\mathrm{NaCl}$ Concentrations and $\mathrm{pH}$ Values}

The growth curve of LD532 bacteria was studied in the liquid culture medium. The composition of the liquid medium was as following: ( $\mathrm{g} \mathrm{L}^{-1}$ deionized water) beef extract 5.0, tryptone 10.0, $\mathrm{NaCl} 100.0$, and the $\mathrm{pH}$ 7.2. The concentration of LD532 bacteria was measured with the spectrophotometer (722s, Shanghai Precision and Scientific Instrument Corporation, China) at $600 \mathrm{~nm}$. At the same time, the fermentation liquid was used as liquid seed when the value measured with the spectrophotometer at $600 \mathrm{~nm}$ was about 0.9 or so.

The growth of LD532 bacteria under different salt $(\mathrm{NaCl})$ concentrations was studied. The concentration of $\mathrm{NaCl}$ was set as $3,5,8,10,12,15,18$, and $20 \%(\mathrm{w} / \mathrm{v})$. The above liquid seed was inoculated into the liquid culture medium with different concentration of $\mathrm{NaCl}$ by $1 \%$ of inoculation volume and incubated at $130 \mathrm{rpm}$ and $30{ }^{\circ} \mathrm{C}$. After $24 \mathrm{~h}$ the concentration of LD532 bacteria was measured with the spectrophotometer at $600 \mathrm{~nm}$.

The growth of LD532 bacteria under different $\mathrm{pH}$ values was also studied. The $\mathrm{pH}$ value of the above liquid medium was adjusted to 5.0, 5.5, 6.0, 6.5, 7.0, 7.5, 8.0, 8.5, 9.0 and 9.5, respectively. The concentration of LD532 bacteria was measured with the spectrophotometer at $600 \mathrm{~nm}$ after $24 \mathrm{~h}$.

\subsection{Growth and $\mathrm{pH}$ Curves of LD532 Bacteria at Different $\mathrm{Mg} / \mathrm{Ca}$ molar ratios}

The growth and $\mathrm{pH}$ curves of LD532 bacteria at different $\mathrm{Mg} / \mathrm{Ca}$ ratios were studied. The concentration of $\mathrm{Ca}^{2+}$ stock solution was $0.01 \mathrm{M}$. $\mathrm{MgSO}_{4}(2 \mathrm{M}), \mathrm{MgCl}_{2}(2 \mathrm{M}), \mathrm{Na}_{2} \mathrm{CO}_{3}(2 \mathrm{M})$ and $\mathrm{NaHCO}_{3}(1 \mathrm{M})$ mother liquor was prepared according to the conventional method. The composition of the liquid medium was as following: ( $\mathrm{g} \mathrm{L}^{-1}$ deionized water) beef extract 5.0, tryptone 10.0, $\mathrm{NaCl}$ 150.0. $3 \mathrm{~mL}$ of $\mathrm{Na}_{2} \mathrm{CO}_{3}(2 \mathrm{M})$ and $6 \mathrm{~mL}$ of $\mathrm{NaHCO}_{3}(1 \mathrm{M})$ was added into each $150 \mathrm{~mL}$ culture medium, and the $\mathrm{pH}$ was adjusted to 7.3. Different $\mathrm{Mg} / \mathrm{Ca}$ ratios were set as $0,2,4,6,8$, and 10, each concentration gradient was set three control groups and three experimental groups. All the cultures were incubated at $130 \mathrm{rpm}$ and $30{ }^{\circ} \mathrm{C}$ in the constant temperature shaker. The concentration of LD532 bacteria was measured with the spectrophotometer at $600 \mathrm{~nm}$ at different time interval. The $\mathrm{pH}$ values were measured using a $\mathrm{pH}$ indicator (PHS-3, Jiangsu Jiangfen Instrument and Equipment Company, China) at different time interval.

\subsection{Determination of Carbonic Anhydrase Activity of C. israelensis LD532 Bacterial in Culture Solution}

In order to understand the biomineralization mechanism of $C$. israelensis LD532 bacteria, CA activity of $C$. israelensis LD532 bacteria in the liquid culture medium was examined. CA activity was detected according to the method supplied by Smith and Ferry [34] and one unit of CA was defined as the amount of enzyme releases $1 \mu \mathrm{mol}$ of $p$-nitro phenol per minute.

\subsection{Characterization of Carbonates Induced by C. israelensis LD532 Bacteria}

Precipitates in the control and experimental groups at different $\mathrm{Mg} / \mathrm{Ca}$ molar ratios were transferred from the bottom of the flask to $4 \mathrm{~mL}$ centrifugal pipe, stood still for 10 minutes. In order 
to fully get rid of the bacteria the supernatants were discarded and the deposit were washed with distilled water and anhydrous ethanol 3 times, respectively, and then dried in air at room temperature.

In order to identify the mineral phases of the carbonates induced by C. israelensis LD532 at different $\mathrm{Mg} / \mathrm{Ca}$ ratios, the above precipitates were studied by XRD (D/Max-RC, Rigaku company, Japan), with $2 \theta$ angle from $10{ }^{\circ} \mathrm{C}$ to $80^{\circ} \mathrm{C}$, a step size of 0.02 and a count time of $8^{\circ} \mathrm{min}^{-1}$. At the same time, to further determine whether organic functional groups exist in carbonate minerals, the above precipitates were also analyzed by FTIR (Nicolet 380, Thermo Fisher Scientific Inc., Massachusetts, American) with a scanning range of 4000-400 $\mathrm{cm}^{-1}$.

The shapes, sizes and micromorphologies of the above precipitates were also observed. The mineral precipitates in the control and the experimental groups were sprayed with platinum $(\mathrm{Pt})$ in vacuum and observed with SEM (Hitachi S-4800, Japan) after they were dried naturally. The elemental composition of mineral precipitates was analyzed by EDS (EDAX, America).

\subsection{Minerals on the Surface of C. israelensis LD532 bacteria by HRTEM, SAED and EDS Analyses}

In order to study whether the nucleation sites of minerals were on the EPS of $C$. israelensis LD532 bacteria, C. israelensis LD532 bacterial suspension in the experimental group at $\mathrm{Mg} / \mathrm{Ca}$ molar ratio of 2 was dripped onto a copper grid and then observed with HRTEM (JEM-2100, Japan) after drying naturally. The crystal structures and elemental composition of the precipitates on the EPS were analyzed with SAED and EDS, respectively.

\subsection{Ultra-thin Slices Analysis of Chromohalobacter israelensis LD532 Bacteria with TEM}

The ultra-thin slices of $C$. israelensis LD532 bacterial cells, which had been cultivated for 40 days, were made as follows: $10 \mathrm{~mL}$ of LD532 bacterial fermentation liquid at Mg/Ca molar ratio of 2 was centrifuged at a speed of $3000 \mathrm{rpm}$ for 5 minutes, the supernatant was discarded and the deposit was washed 3 times with phosphate buffer $\left(\mathrm{NaH}_{2} \mathrm{PO}_{4} \bullet 2 \mathrm{H}_{2} \mathrm{O} 3.1167 \mathrm{~g} / \mathrm{L}, \mathrm{Na}_{2} \mathrm{HPO}_{4} \bullet 12 \mathrm{H}_{2} \mathrm{O} 20.7472\right.$ $\mathrm{g} / \mathrm{L}, \mathrm{pH}$ 7.4) to remove the remaining culture medium, the cells were fixed with $1 \mathrm{~mL}$ of $2.5 \%$ glutaraldehyde and $1 \%$ osmic acid for $1 \mathrm{~h}$ and washed with phosphate buffer for 3 times, the cells were then gradually dehydrated by acetone solutions according to the following order: $30 \%(15 \mathrm{~min})$ $-50 \%(15 \mathrm{~min})-70 \%(15 \mathrm{~min})-80 \%(15 \mathrm{~min})-90 \%(15 \mathrm{~min})-95 \%(15 \mathrm{~min})-100 \%(15 \mathrm{~min})-100 \%$ (15min) $-100 \%(15 \mathrm{~min}), 1 \mathrm{~mL}$ of $30 \%$ epoxy resin solution was added and the cells were embedded. Finally these completed ultra-thin slices were analyzed with TEM (JEM-2100, Japan).

\section{Results}

\subsection{Identification of C. israelensis LD532 bacteria}

The bacterium $C$. israelensis LD532, isolated after enrichment and purification, is a Gram-negative, strictly aerobic, and rod-shaped bacterium with a width of about 0.5 to $0.8 \mu \mathrm{m}$ and a length of about 0.7 to $1.5 \mu \mathrm{m}$ (Table 1, Figure 1a and b). Bacteria LD532 can move in the semisolid medium (Table 1), indicating that the bacteria had certain motility. Bacteria commonly get their motility from external structures called flagella. It can be seen from Figure 1a and $b$ that more than one flagellum grows on the surface of bacterium LD532, which also proved its motility (Table 1). The results of the physiological and biochemical identification are shown in Table 1. The result of triple sugar iron agar, amylase, citrate, EPS, moveability and urease is positive respectively, while the result of V-P, catalase, sulfureted hydrogen, methyl red, cellulase, and esterase is negative respectively. 
Table.1 To further state the characteristics of Chromohalobacter israelensis, the physiological and biochemical identification were carried out.

\begin{tabular}{ccc}
\hline test item & LD532 & $\begin{array}{c}\text { Standard } \\
\text { Chromohalobacter } \\
\text { israelensis }\end{array}$ \\
\hline Triple Sugar Iron Agar & + & + \\
V-P & - & - \\
Catalase & - & - \\
Sulfureted Hydrogen & - & - \\
Amylase & + & + \\
Methyl Red & - & - \\
Citrate & + & + \\
Cellulase & - & - \\
EPS & + & + \\
Moveability & + & + \\
Esterase & - & + \\
Urease & + & \\
\hline
\end{tabular}

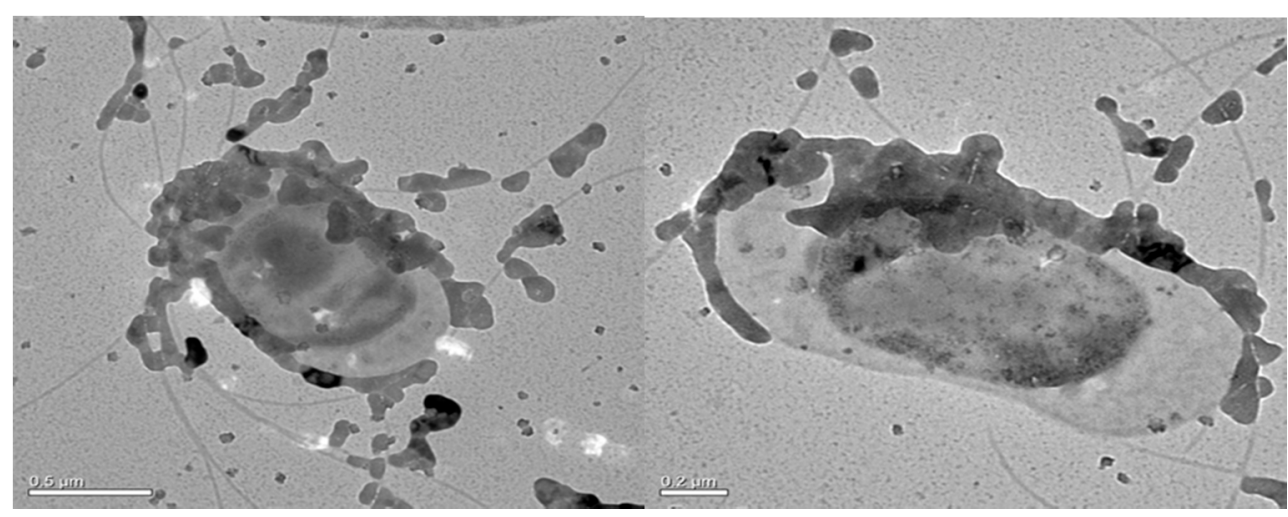

(a)

(b)

Figure 1. The morphology and phylogenetic tree of LD532 bacteria. (a) and (b) HRTEM images.

The 16S rDNA sequence length of LD532 was $1452 \mathrm{bp}$ via DNAMAN 8.0 to joint two opposite sequences. A nucleotide homology comparison was conducted with the BLAST program. A phylogenetic tree was constructed with the MEGA 5.0 software using the neighbor-joining method (Figure 1c). The full-length 16S rDNA sequence of strain LD532 shared $>97 \%$ nucleotide sequence homology with the 16S rDNA sequences of many Chromohalobacter strains in GenBank, and $98 \%$ homology with those of three strains of $C$. israelensis. The LD532 strain was most closely related to $C$. israelensis on the phylogenetic tree based on $16 \mathrm{~S}$ rDNA sequences, which was consistent with the physiological and biochemical characteristics of the isolated strain. Thus, strain LD532 was identified as C. israelensis. 


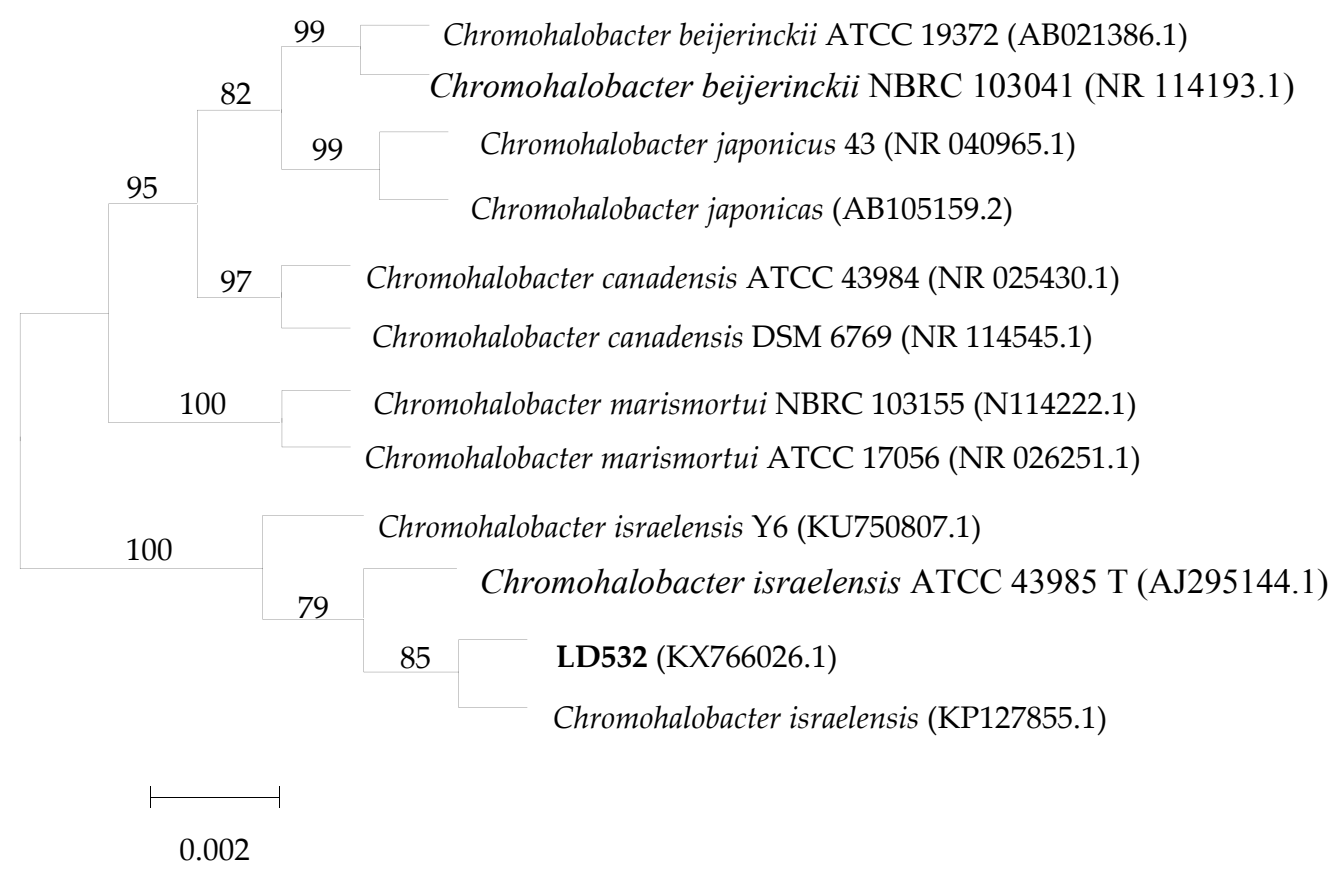

(c)

Figure 1. The morphology and phylogenetic tree of LD532 bacteria. (c) Phylogenetic tree constructed with a neighbor-joining analysis based on a sequence alignment of bacterial 16S rDNA genes.

\subsection{The Growth Curves of C. israelensis LD532 Bacteria in Liquid Culture Medium at Different salt Concentrations and $p H$ Values}

Figure 2a shows the growth curve of bacterial strain LD532 incubated in the liquid culture medium with $\mathrm{NaCl}$ concentration of $15 \%(\mathrm{w} / \mathrm{v})$ at $30{ }^{\circ} \mathrm{C}$ for 24 hours, and it can be seen that bacteria grow slowly at the beginning of three hours, and cells are in logarithmic growth stage between $3-45$ hours, after 45 hours, the bacterial growth enters recession. Figure $2 b$ shows the growth curve of bacterial strain LD532 incubated in the liquid culture medium with different $\mathrm{NaCl}$ concentrations at $30{ }^{\circ} \mathrm{C}$ for 24 hours, and the result indicated that the bacteria grew best at $10 \%$ of $\mathrm{NaCl}$ concentration during the range of $\mathrm{NaCl}$ concentration from $3 \%$ to $20 \%$. Figure $2 \mathrm{c}$ shows the growth curve of bacterial strain LD532 incubated in the liquid culture medium with different $\mathrm{pH}$ values and $15 \%$ of $\mathrm{NaCl}$ concentration at $30{ }^{\circ} \mathrm{C}$ for 24 hours, and the result showed that bacteria grew normally in a $\mathrm{pH}$ range from 5.0 to 8.5 , but the cell concentration declined sharply when $\mathrm{pH}$ beyond 8.5 and bacteria almost stopped growing at $\mathrm{pH} 9.0$ and 9.5. According to the above results, culture conditions such as the liquid culture medium, $\mathrm{pH} 7.3$, and $15 \%$ of $\mathrm{NaCl}$ concentration could be used in the following carbonates precipitation experiments induced by LD532 bacteria.

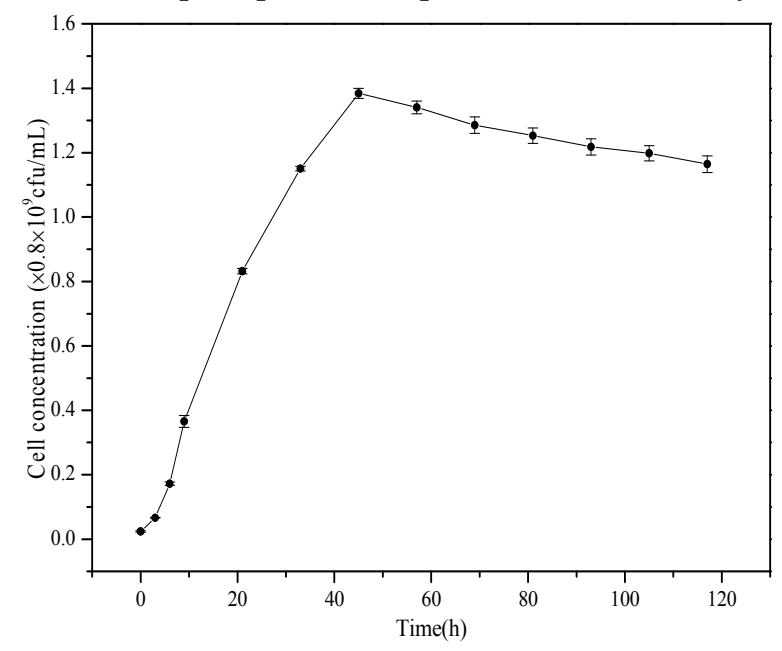


(a)

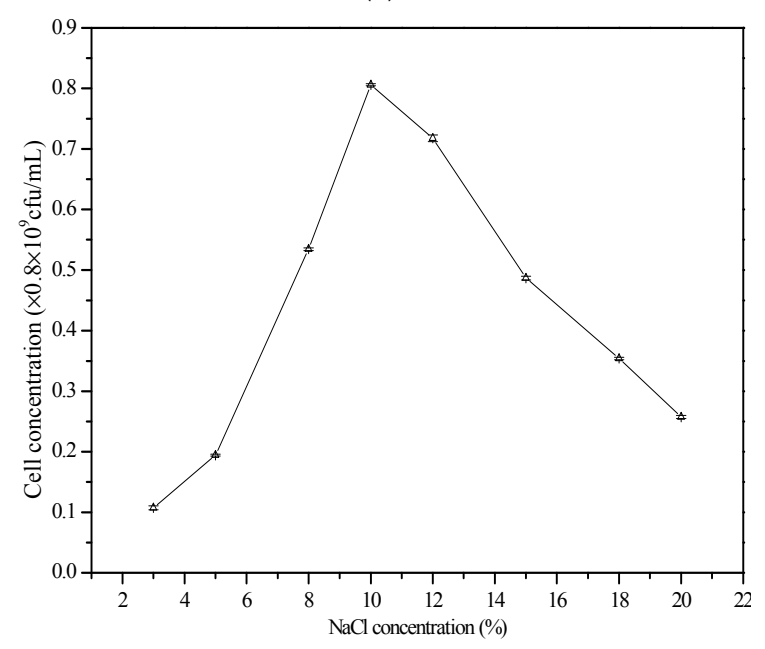

(b)

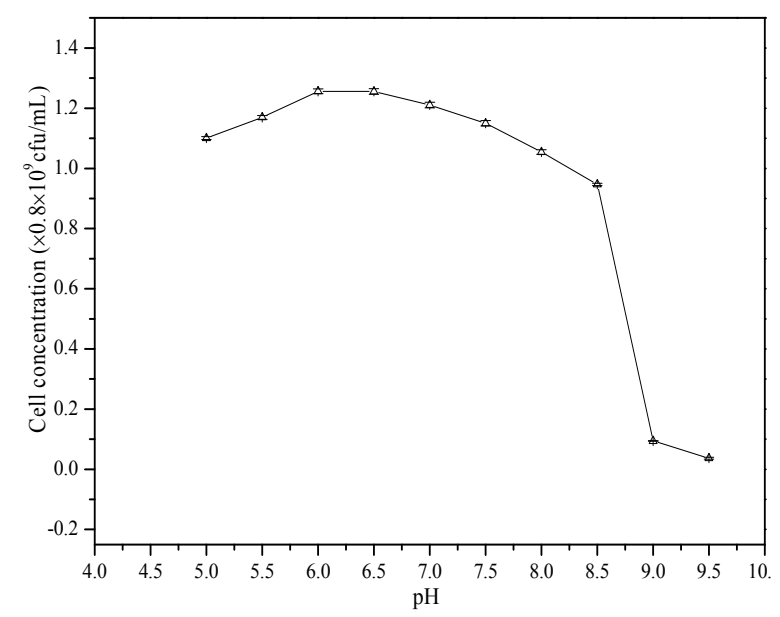

(c)

Figure 2. Characterization of LD532 bacteria. (a) growth curve; (b) cell concentration of LD532 bacteria after the 24hs' cultivation at different $\mathrm{NaCl}$ concentrations; (c) cell concentration of LD532 bacteria after the 24hs' cultivation at different $\mathrm{pH}$ values.

\subsection{Growth and $p H$ Curves of LD532 Bacteria at Different $\mathrm{Mg} / \mathrm{Ca}$ molar ratios and CA Activity Curve}

Figure 3a shows the growth curves of LD532 bacteria at different $\mathrm{Mg} / \mathrm{Ca}$ ratios and $15 \%$ of $\mathrm{NaCl}$ concentration, and it can be seen from the Figure 3a that at each $\mathrm{Mg} / \mathrm{Ca}$ ratio $(0,2,4,6,8$, and 10) bacteria grows slowly in the time range of $0-9$ hours, the cell concentrations sharply increase from $9-50$ hours in the logarithmic growth phase, and the bacteria are stable phase from $50-100$ hours, in which phase the cell concentration of LD532 bacteria significantly increases with increasing $\mathrm{Mg} / \mathrm{Ca}$ ratios. According to the above results, it could be obtained that a higher $\mathrm{Mg}^{2+}$ concentration within the certain scope could promote the growth of LD532 bacteria in this experiment.

In order to expound the mechanism of the increasing $\mathrm{pH}$ values, the changes of CA activity were also investigated. Figure 3b shows the CA activity curve of bacterial strain LD532 at $\mathrm{Mg} / \mathrm{Ca}$ ratio of 2 and $15 \%$ of $\mathrm{NaCl}$ concentration. By comparing with Figure 3a, it could be obtained that CA was a synchronous synthase because of the coupling of this enzyme with the growth of bacteria. At the beginning, the quantity of released CA is very few, the production increases sharply from 25 to $300 \mathrm{U} / \mathrm{mL}$ or so along with the growth of bacteria at logarithmic phase, decreases during bacterial stationary phase, and keeps at $75 \mathrm{U} / \mathrm{mL}$ or so in the end.

Figure $3 \mathrm{c}$ shows the $\mathrm{pH}$ curves of LD532 bacteria at different $\mathrm{Mg} / \mathrm{Ca}$ ratios and $15 \%$ of $\mathrm{NaCl}$ concentration, and it can be seen from Figure $3 \mathrm{c}$ that $\mathrm{pH}$ increases sharply from 7.3 to 8.7 during 0 - 
9 hours due to the release of ammonia produced by the liquid seed, declines slowly from 8.7 to 8.3 during $9-24$ hours owing to the release of carbon dioxide produced by LD532 bacteria, then a slight increase from 8.3 to 8.8 or so occurs in the $\mathrm{pH}$ values during the time range of $24-60$ hours, in which period the concentration of CA secreted by LD532 bacteria is increasing from 25 to 300 $\mathrm{U} / \mathrm{mL}$ or so (Figure $3 \mathrm{~b}$ ), $\mathrm{pH}$ values decrease from 8.8 to 8.4 or so during the period of $60-96$ hours, in which time CA activity declines from 300 to $75 \mathrm{U} / \mathrm{mL}$ (Figure 3b), and at last $\mathrm{pH}$ values increase slowly from 8.5 to 9.0 or so due to the urease activity (Table 1) in the time range of $96-168$ hours, but something a bit more special that $\mathrm{pH}$ value increases to 8.8 or so at $\mathrm{Mg} / \mathrm{Ca}$ ratio of 10 . The values of $\mathrm{pH}$ are stable during the period of time from $168-220$ hours, 9.0 or so at $\mathrm{Mg} / \mathrm{Ca}$ ratio of 0 , $2,4,6$, and 8 , and 8.8 or so at $\mathrm{Mg} / \mathrm{Ca}$ ratio of 10 . At the $\mathrm{pH}$-stable phase, $\mathrm{pH}$ values decreased with increasing $\mathrm{Mg} / \mathrm{Ca}$ ratios, which was closely connected with the fact that with higher $\mathrm{Mg} / \mathrm{Ca}$ ratios the higher cell concentrations of LD532 bacteria could produce more amount of carbon dioxide. According to the above results, $\mathrm{pH}$ values could reach 9.0 or so due to $\mathrm{CA}$ and urease activity, which was taken as premise condition for the bacterially induced carbonates biomineralization.

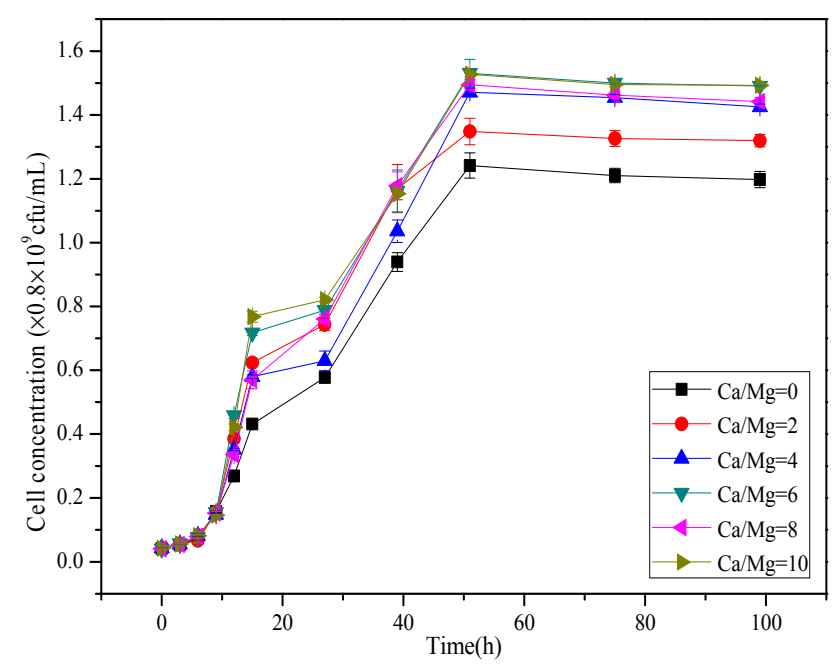

(a)

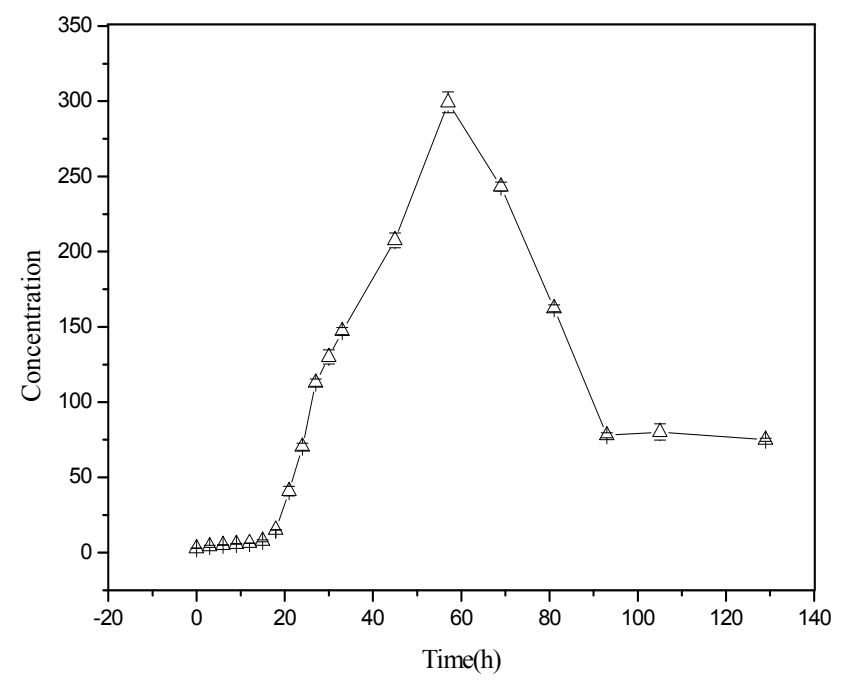

(b) 


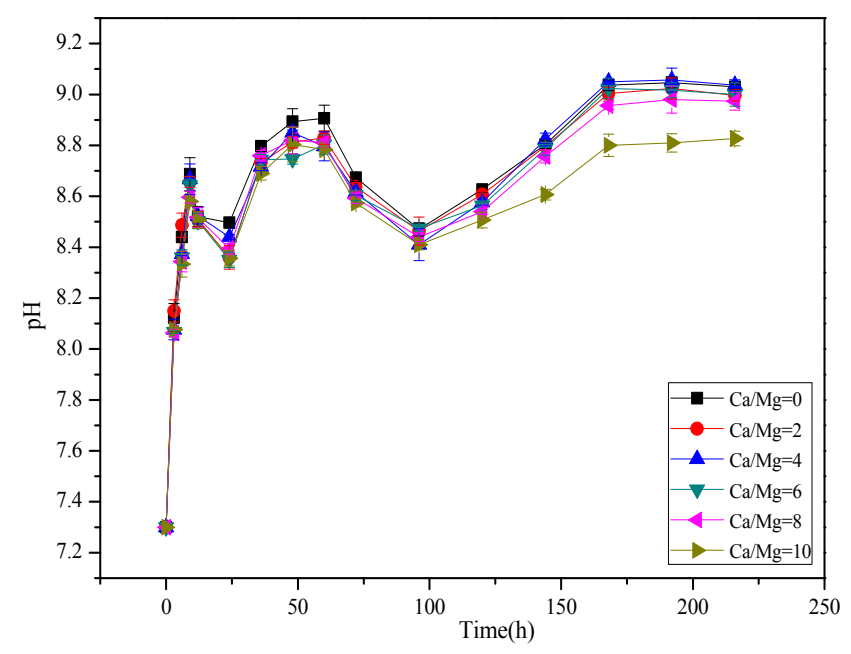

(c)

Figure 3. Growth curves, enzyme activity curve and $\mathrm{pH}$ curves of LD532 bacteria at different $\mathrm{Mg} / \mathrm{Ca}$ molar ratios. (a) growth curves; (b) carbonic anhydrase activity curve; (c) pH curves.

\subsection{Carbonate Minerals analyzed by XRD and FTIR}

In order to further analyze the mineral phases and structural characteristics of the precipitates induced by $C$. israelensis LD532 bacteria, the carbonate precipitates cultured 15 days were analyzed with XRD. The results of the mineralogical analysis are displayed in Figure 4 and Figure 5. It can be obtained from Figure 4 that the minerals produced in the control and experimental group of $\mathrm{MgSO}_{4}$ aqueous solution are calcite at $\mathrm{Mg} / \mathrm{Ca}$ ratio of 0 (Figure $4 \mathrm{a} \& \mathrm{~b}$ ), and monohydrocalcite is the only precipitation in the control group at other $\mathrm{Mg} / \mathrm{Ca}$ ratios (Figure 4a). While there is a significant difference in the mineral phases between the control group and the experimental group at $\mathrm{Mg} / \mathrm{Ca}$ ratio of 2, Mg-calcite, besides of monohydrocalcite, was formed in the experimental group (Figure $4 \mathrm{~b})$. Magnesium contents of Mg-calcite were detected as $27 \%$ according to calculation formula [35, 36]. The minerals in the experimental group at other $\mathrm{Mg} / \mathrm{Ca}$ ratios are the same as those in the control group. It is worth noting that in the control group the diffraction peak intensity of (222) crystal plane is higher than that of (411) crystal plane at $\mathrm{Mg} / \mathrm{Ca}$ ratio of 4 and 6 (Figure $4 \mathrm{a}$ ), opposite to the standard diffraction peak intensity of monohydrocalcite, indicating that the preferred orientation of monohydrocalcite occurred in this experiment.

Figure 5 shows the mineral phases and crystal structures of the precipitates in the control and experimental group in $\mathrm{MgCl}_{2}$ aqueous solution. It can be obtained from Figure $5 \mathrm{a}$ that the mineral is calcite at $\mathrm{Mg} / \mathrm{Ca}$ molar ratio of 0 and monohydrocalcite at other $\mathrm{Mg} / \mathrm{Ca}$ molar ratios, consistent with the result shown in Figure 4a. There was a little difference between these two groups, that was, the preferred orientation occurred to the mineral crystals when using $\mathrm{MgSO}_{4}$ and while there was no such phenomena in other group, indicating that the sources of $\mathrm{Mg}^{2+}$ had a certain influence on the crystal structure. It can be obtained from Figure $5 \mathrm{~b}$ that the mineral is calcite at $\mathrm{Mg} / \mathrm{Ca}$ ratio of 0 , Mg-rich calcite and aragonite at $\mathrm{Mg} / \mathrm{Ca}$ ratio of 2, and monohydrocalcite at other $\mathrm{Mg} / \mathrm{Ca}$ ratios, indicating the mineral phases were significantly different from those shown in Figure $4 \mathrm{~b}$. From the above result, it was proved that the sources of $\mathrm{Mg}^{2+}$ had an important effect on the new formed mineral phases and appear preferred orientation. 


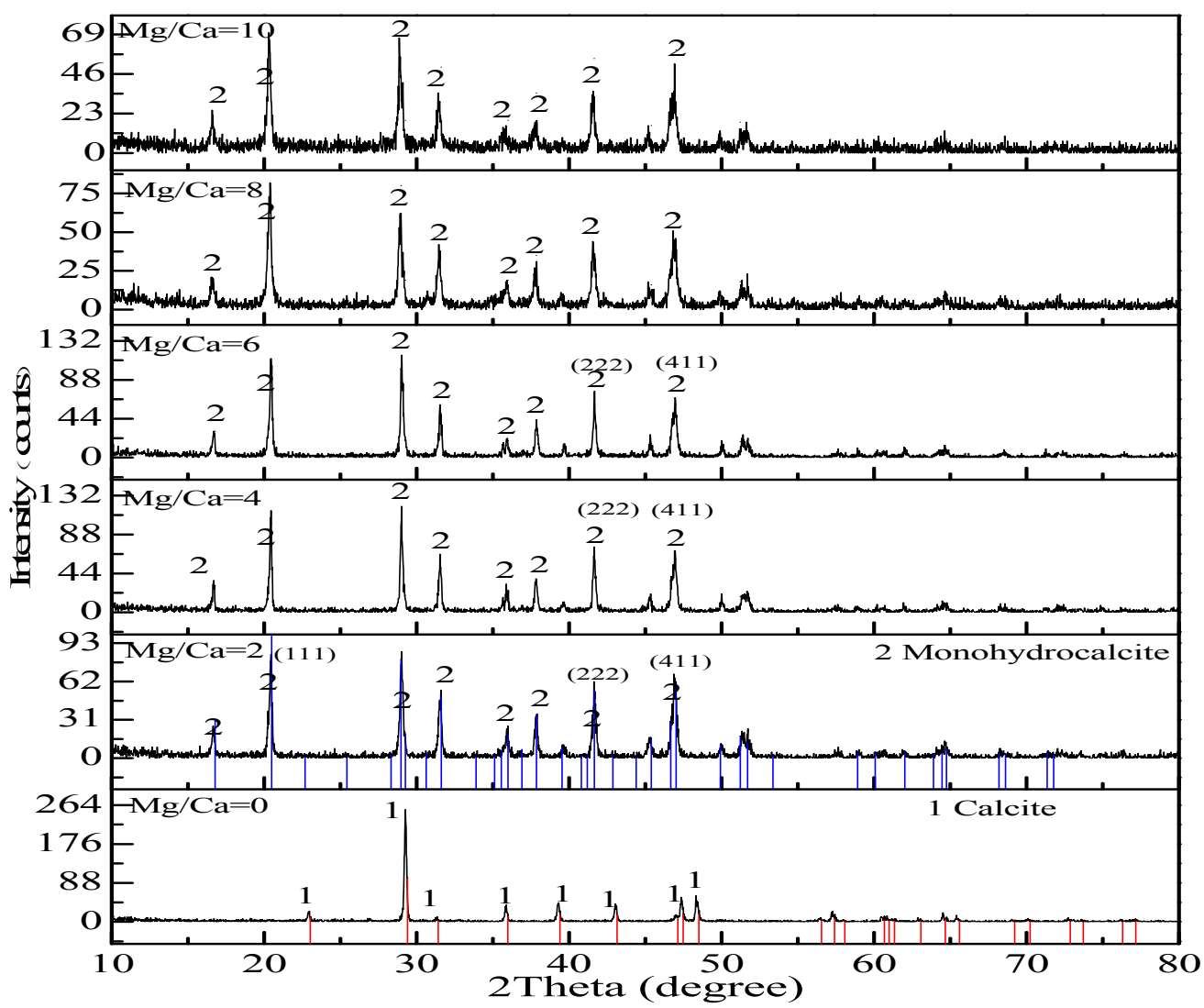

(a)

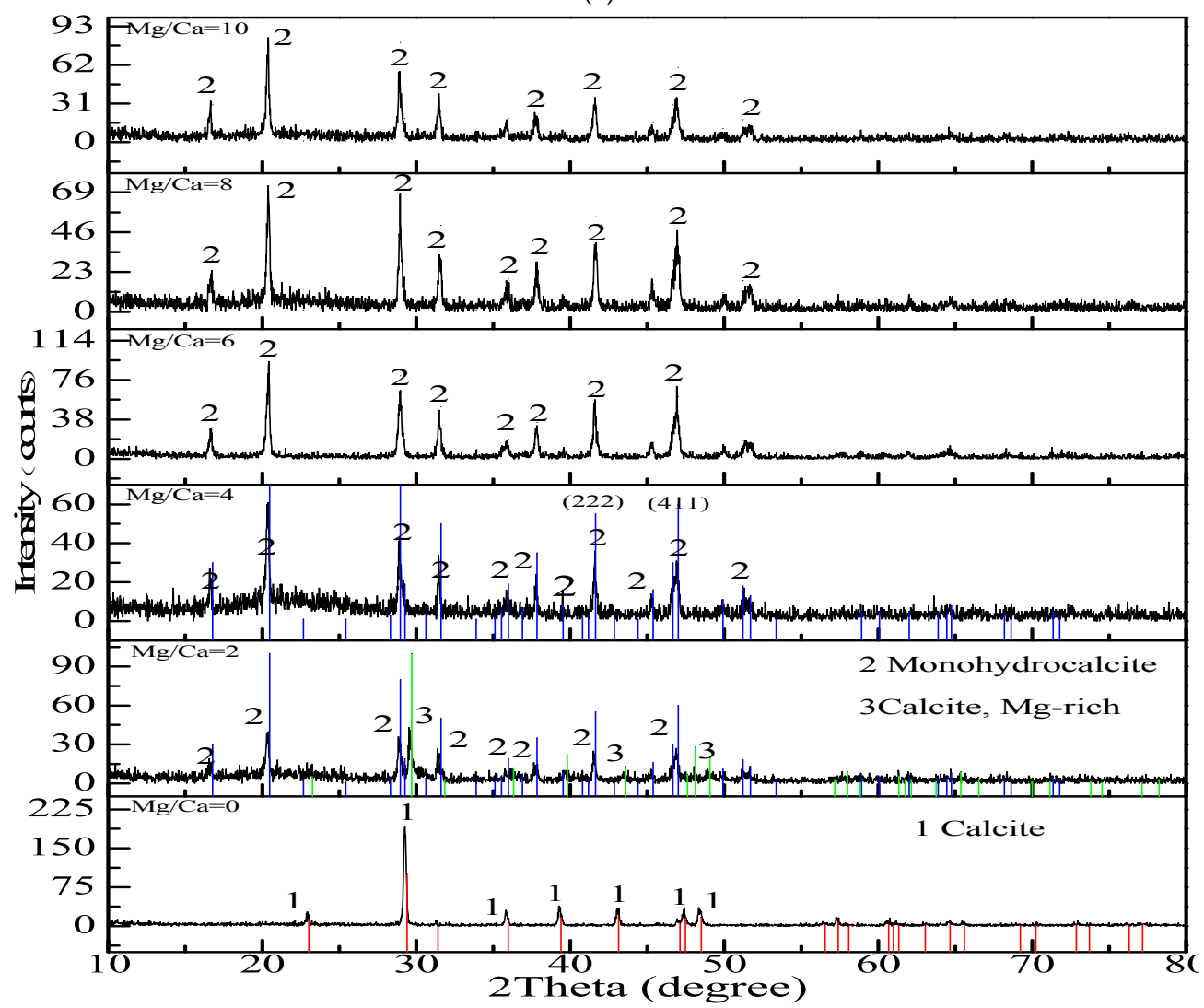

(b)

Figure 4. XRD patterns of the minerals at $15 \% \mathrm{NaCl}$ and different $\mathrm{Mg} / \mathrm{Ca}$ molar ratios $\left(\mathrm{Mg}^{2+}\right.$ from $\left.\mathrm{MgSO}_{4} \cdot 7 \mathrm{H}_{2} \mathrm{O}\right)$ after 15 days of cultivation. (a) the control group; (b) the experimental group. 


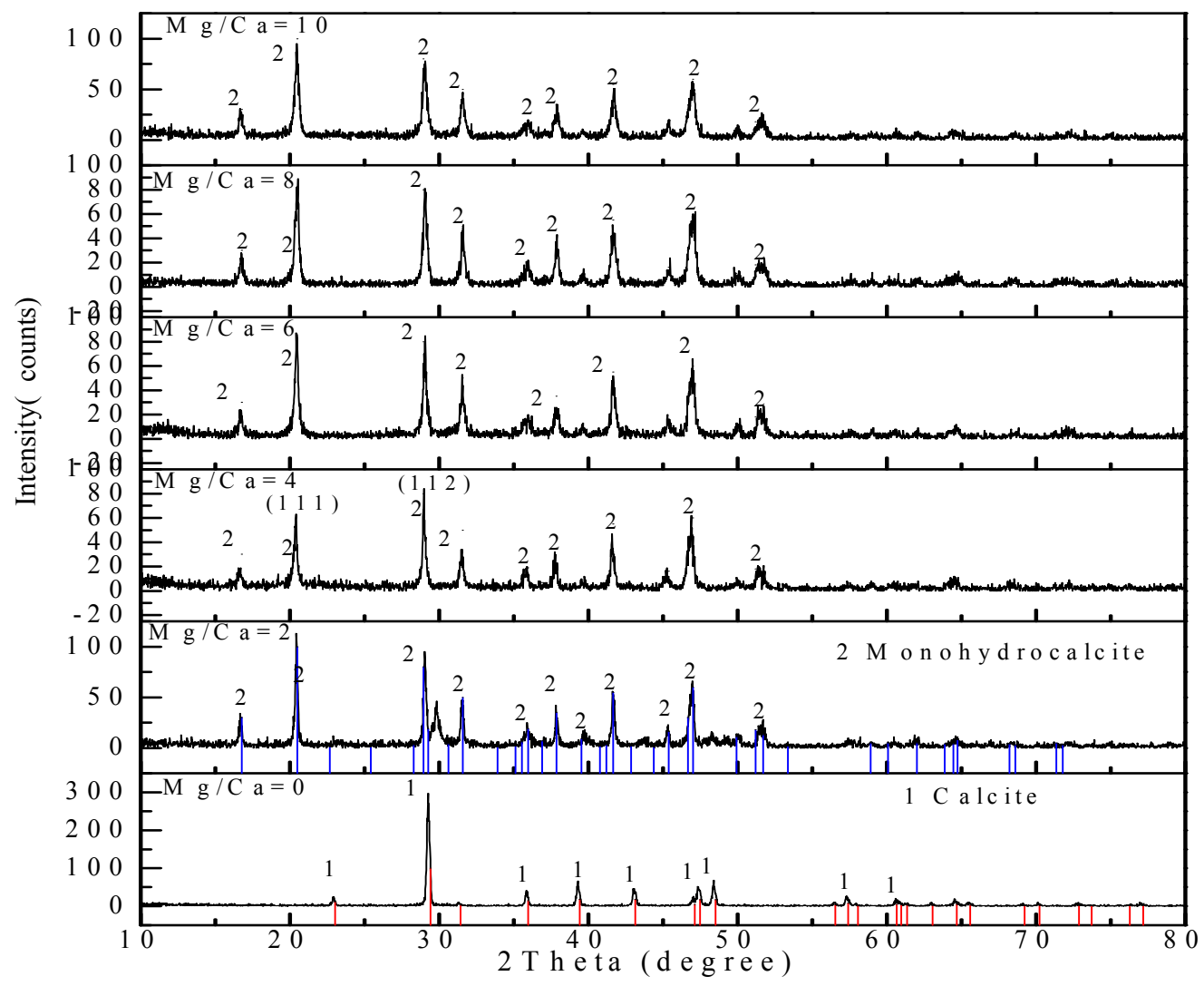

(a)

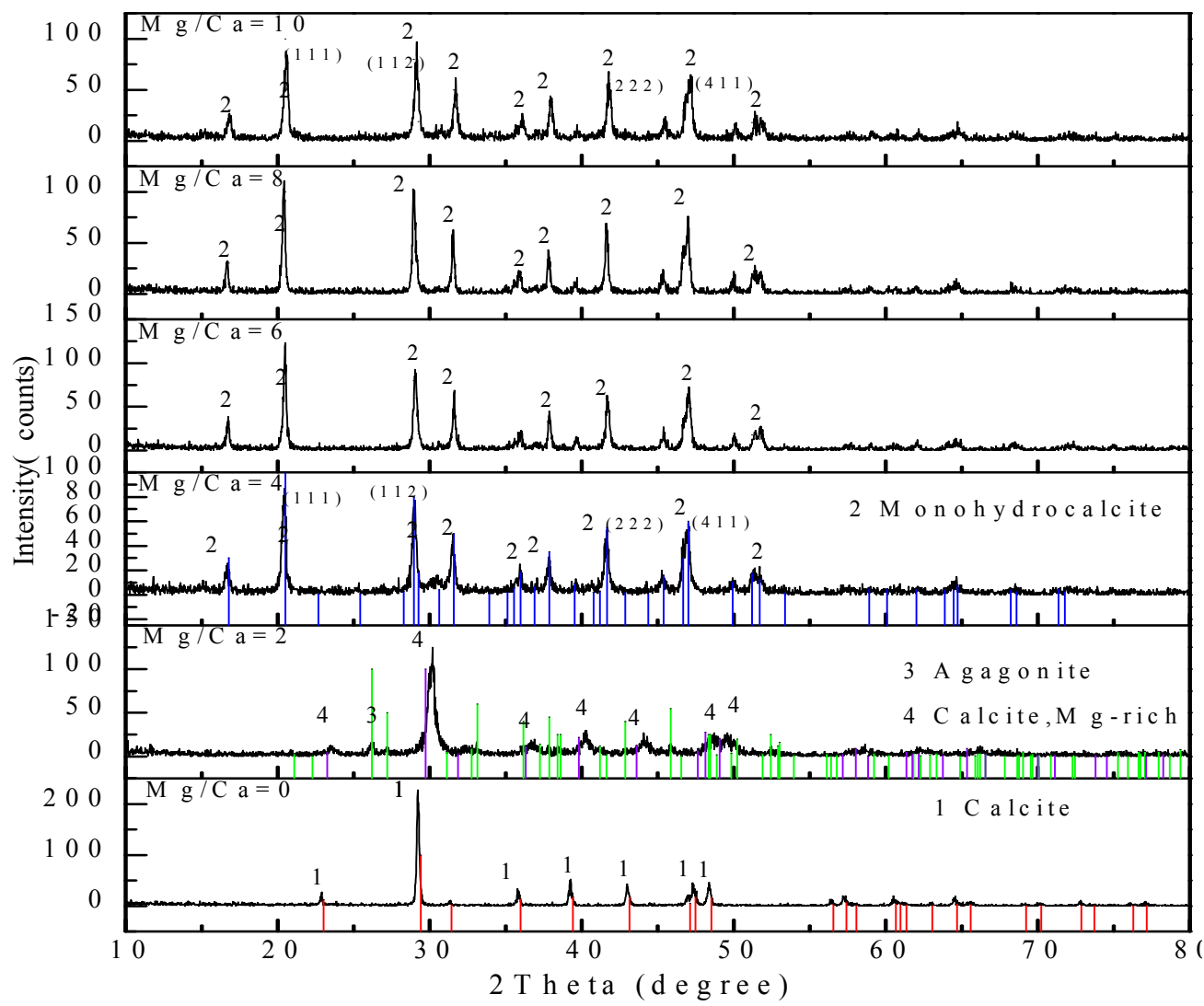

(b)

Figure 5. XRD patterns of the minerals at $15 \% \mathrm{NaCl}$ and different $\mathrm{Mg} / \mathrm{Ca}$ molar ratios $\left(\mathrm{Mg}^{2+}\right.$ from $\left.\mathrm{MgCl}_{2} \cdot 6 \mathrm{H}_{2} \mathrm{O}\right)$ after 15 days of cultivation. (a) the control group; (b) the experimental group. 
The result of FTIR in $\mathrm{MgCl}_{2}$ solution in experimental group of $\mathrm{Mg} / \mathrm{Ca}$ molar ratio of 2 is shown Figure 6. FTIR of Mg-rich calcite displayed in Figure $6 a$, Figure $6 \mathrm{~b}$ is an enlarged view of the 2800-3000 $\mathrm{cm}^{-1}$ spectral segment in Figure 6a, where it is seen that there are $\mathrm{C}-\mathrm{H}$ methylene vibrational bands $\left(2925 \mathrm{~cm}^{-1}\right)$ and C-H methyl vibrational bands $\left(2979 \mathrm{~cm}^{-1}\right)[37,38]$, indicating that the organic functional groups were contained in the formation process of Mg-rich calcite minerals.

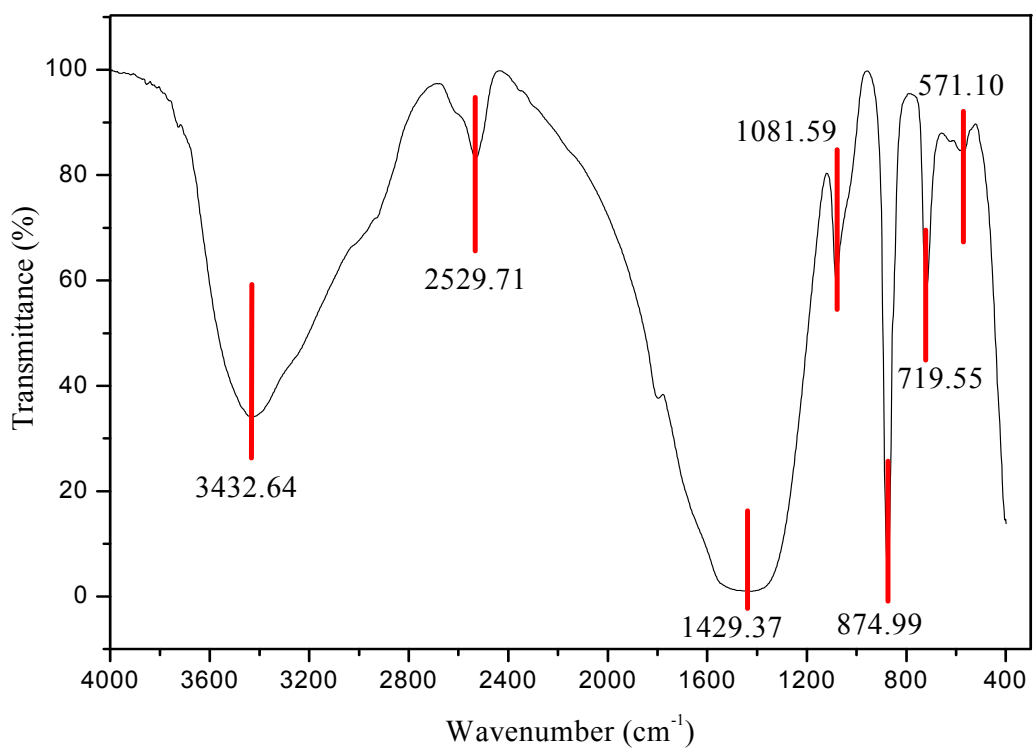

(a)

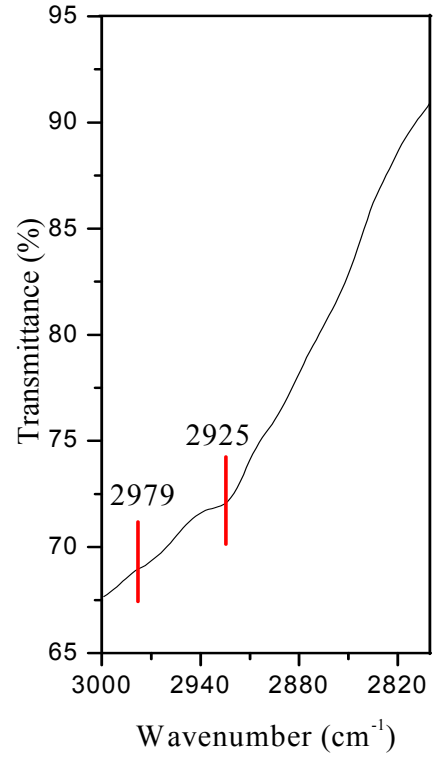

(b)

Figure 6. FTIR spectrogram of Mg-rich calcite formed in $\mathrm{Mg} / \mathrm{Ca}$ molar ratio of 2 in experimental group in $\mathrm{MgCl}_{2}$ solution. (a) FTIR spectrogram of Mg-rich calcite form $4000 \mathrm{~cm}^{-1}$ to $400 \mathrm{~cm}^{-1}$; (b) partial enlarged view of the spectrogram from $3000 \mathrm{~cm}^{-1}$ to $2800 \mathrm{~cm}^{-1}$.

\subsection{Carbonates Minerals analyzed by SEM and EDS}

In order to analyze the effect of the micromorphology changes of minerals at different conditions, the precipitates in the control and experimental group were observed using SEM and EDS. The results of the micromorphology analysis of the minerals in $\mathrm{MgSO}_{4}$ aqueous solution are shown in Figure 7. It can be seen from Figure 7a and $b$ that there are two kinds of morphology of calcite, one is rhombohedron and the other is spherulite, the rhombohedron calcite crystals grow up in a stepwise manner with the height of the growth step about $1 \mu \mathrm{m}$ and the calcite spherulite with a very rough surface is about $10 \mu \mathrm{m}$ in diameter at $\mathrm{Mg} / \mathrm{Ca}$ ratio of 0 . Figure $7 \mathrm{c}$ shows the dumbbell-shaped monohydrocalcite with a length of about $12-15 \mu \mathrm{m}$ is covered with a large quantity of hedrite dissipative crystals (Figure $7 \mathrm{~d}$ ) at $\mathrm{Mg} / \mathrm{Ca}$ ratio of 2 . The result of EDS analysis of the minerals marked with a white square in Figure 6c shows that the mainly elements include $\mathrm{Ca}, \mathrm{C}$, $\mathrm{O}$, and a little $\mathrm{Mg}, \mathrm{Al}$ and $\mathrm{Na}$ (Figure $7 \mathrm{~m}$ ). $\mathrm{Mg}$ and $\mathrm{Na}$ came from the culture medium, and $\mathrm{Al}$ came from the upholder under the sample. The minerals formed in the medium at $\mathrm{Mg} / \mathrm{Ca}$ ratio of 4 were dumbbell-shaped, $12-20 \mu \mathrm{m}$ in length (Figure 7e). Figure $7 \mathrm{f}$ shows that the surface of the monohydrocalcite is also covered with a large quantity of hedrite dissipative crystals, nothing but these crystals are more regular than those in Figure 7d. EDS result shows that the elemental composition of the mineral include $\mathrm{Ca}, \mathrm{C}, \mathrm{O}$, and a little $\mathrm{Mg}$, $\mathrm{Al}$ and $\mathrm{Na}$ (Figure $7 \mathrm{n}$ ). Figure $7 \mathrm{~g}$ and $\mathrm{h}$ shows the micromorphology of the calcite in the experimental group at $\mathrm{Mg} / \mathrm{Ca}$ ratio of 0 , which illustrate that LD532 bacteria played an important role in the changes of micromorphology. The calcite becomes irregular with unclear growth step, not rhombohedron or spherulite crystals any more, and the rougher surface is covered with different sizes of irregular bulk crystals, obviously different from those in the control group. The minerals in the culture medium at $\mathrm{Mg} / \mathrm{Ca}$ molar ratio of 2 are mainly cauliflower (Figure 7i), and the surface is composed of particulate crystals (Figure 7j). The elemental composition of minerals includes $\mathrm{Ca}, \mathrm{C}, \mathrm{O}$, and little $\mathrm{Mg}, \mathrm{Al}, \mathrm{Na}$ and $\mathrm{P}$ (Figure 7o). P possibly came from LD532 bacteria. The crystals are elliptic at Mg/Ca molar ratio of 4 (Figure 7k), 
and the surface is covered with many flaky minerals with regular geometric shape (Figure 7l). EDS result shows that the elemental composition of this mineral includes $\mathrm{Ca}, \mathrm{C}, \mathrm{O}$, and little $\mathrm{Mg}, \mathrm{Al}, \mathrm{Na}$ and $\mathrm{P}$ (Figure $7 \mathrm{p}$ ). It can be obtained from Figure 7 that there is a significant difference in the morphology and elemental composition of minerals between the control and experimental group, indicating LD532 bacteria played a vital role in the biomineralization process.

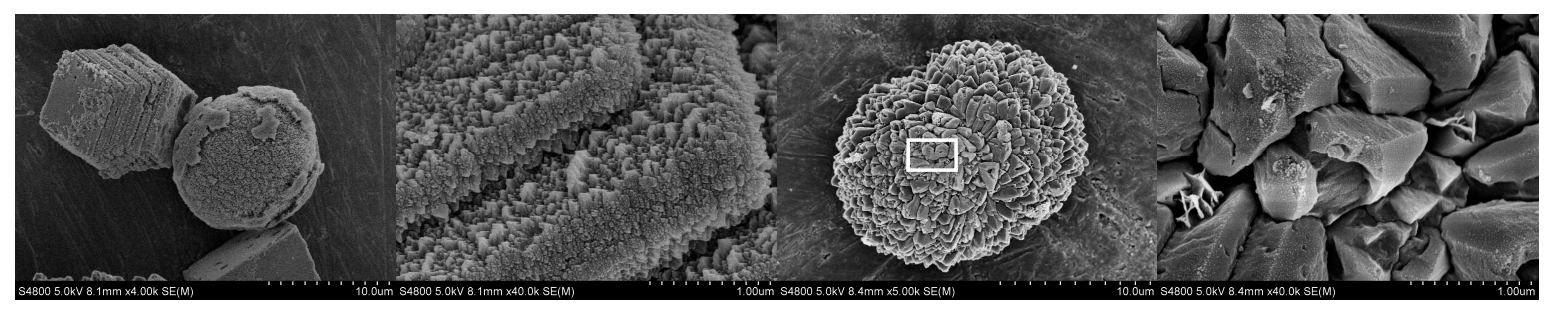

(a)

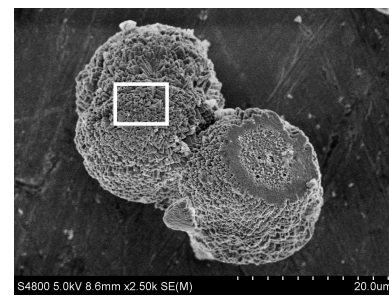

(e)

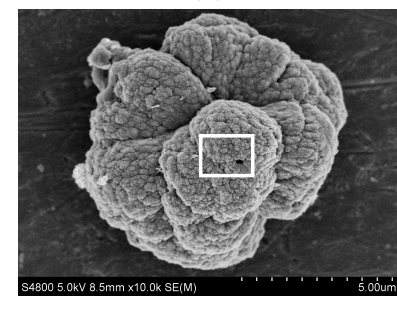

(i)

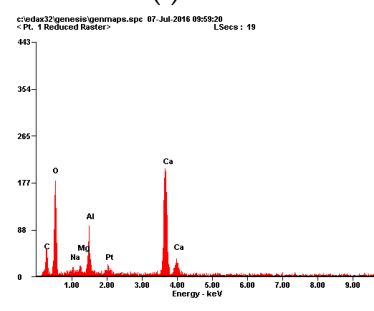

$(\mathrm{m})$ (b)

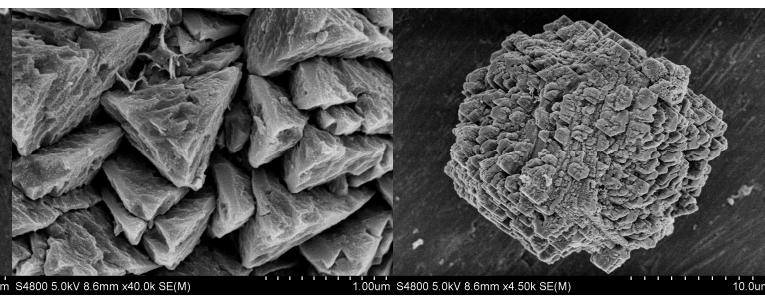

(d)

(g)

(h) (f)

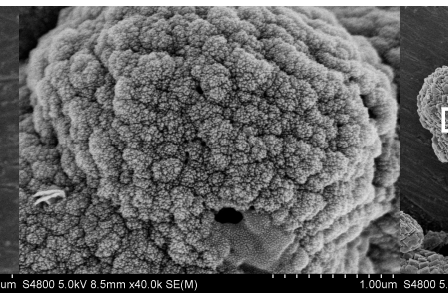

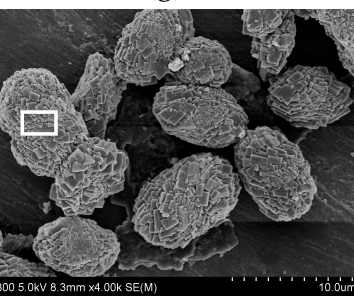

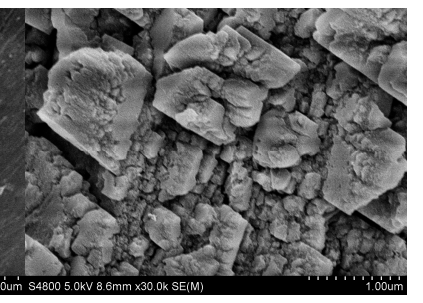

(k)

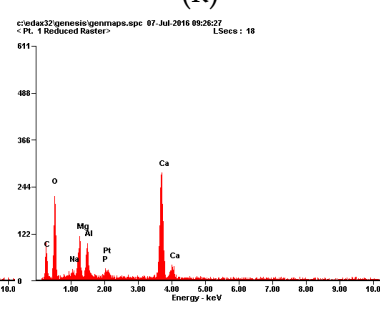

(o)

(n)

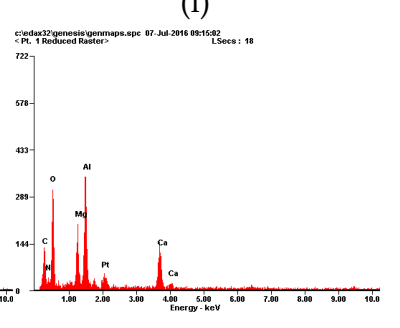

(p)

Figure 7. SEM and EDS images of the minerals in the control group and experimental group at $15 \% \mathrm{NaCl}$ and different $\mathrm{Mg} / \mathrm{Ca}$ molar ratios $\left(\mathrm{Mg}^{2+}\right.$ from $\mathrm{MgSO}_{4} \cdot 7 \mathrm{H}_{2} \mathrm{O}$ ) after 15 days of cultivation. (a), (b) $\mathrm{Mg} / \mathrm{Ca}$ molar ratio of 0 in control group; (c), (d) $\mathrm{Mg} / \mathrm{Ca}$ molar ratio of 2 in control group; (e), (f) $\mathrm{Mg} / \mathrm{Ca}$ molar ratio of 4 in control group; (g), (h) $\mathrm{Mg} / \mathrm{Ca}$ molar ratio of 0 in experimental group; (i), (j) $\mathrm{Mg} / \mathrm{Ca}$ molar ratio of 2 in experimental group; (k), (1) Mg/Ca molar ratio of 4 in experimental group; (m), (n), (o), (p) EDS analysis by the white square, respectively.

Figure 8 shows the micromorphology of the minerals formed in the medium with different concentrations of $\mathrm{MgCl}_{2}$. The calcites at $\mathrm{Mg} / \mathrm{Ca}$ molar ratio of 0 are a large number of irregular rhombohedral crystals with a diameter of 5-8 $\mathrm{m}$ (Figure 8a) and the surfaces of calcites are composed of nano-scale particles (Figure $8 \mathrm{~b}$ ). The spherulite monohydrocalcite is $8-12 \mu \mathrm{m}$ in diameter at $\mathrm{Mg} / \mathrm{Ca}$ molar ratio of 2 (Figure 8c), composed of a large number of fibrous mineral crystals (Figure 8d). EDS analysis shows that the elemental composition of this mineral includes $\mathrm{C}$, $\mathrm{O}, \mathrm{Ca}$, and little $\mathrm{Al}, \mathrm{Mg}$ and $\mathrm{Pt}$ (Figure 8m). Pt comes from the spraying operation in the preparation process of sample. The dumbbell shaped monohydrocalcite shown in Figure 8e, $15-20 \mu \mathrm{m}$ in 
length, is covered with a large quantity of hedrite dissipative crystals (Figure 8f) smaller than those in the $\mathrm{MgSO}_{4}$ medium. EDS result shows that the elemental composition of this mineral includes $\mathrm{Ca}$, $\mathrm{C}, \mathrm{O}$, and little $\mathrm{Mg}, \mathrm{Al}$, and $\mathrm{Na}$ (Figure $8 \mathrm{n}$ ). In the experimental group, bunchy calcite, about $5-10$ $\mu \mathrm{m}$ in length, can be found in Figure $8 \mathrm{~g}$ at $\mathrm{Mg} / \mathrm{Ca}$ molar ratio of 0 , composed of countless smaller rhombohedron calcite (Figure $8 \mathrm{~h}$ ). The minerals are mainly cauliflower and dumbbell-shaped in the culture medium at $\mathrm{Mg} / \mathrm{Ca}$ molar ratio of 2 and the sizes are in the range of $5-8 \mu \mathrm{m}$ (Figure 8i). Cross-type minerals are manifested in Figure $8 \mathrm{j}$ (marked with the red arrows), about $5 \mu \mathrm{m}$ in length. EDS result shows that the elemental composition of this mineral includes $\mathrm{Al}, \mathrm{Ca}, \mathrm{C}, \mathrm{O}, \mathrm{Mg}$, and $\mathrm{P}$ (Figure 8o). The crystals formed in the culture medium at $\mathrm{Mg} / \mathrm{Ca}$ molar ratio of 4 are dumbbell-shaped and the sizes are about $5 \mu \mathrm{m}$ in length (Figure 8k). The micromorphology of this mineral shown in Figure 81 is proved that the surface is covered with a large quantity of microcrystals. EDS result shows that the elemental composition of this mineral includes $\mathrm{Ca}, \mathrm{C}, \mathrm{O}$, and little $\mathrm{Mg}, \mathrm{Al}$, and $\mathrm{P}$ (Figure 8p). From the above result, it could be obtained that there was significant difference in the morphology and elemental composition of the minerals between the control and experimental group.

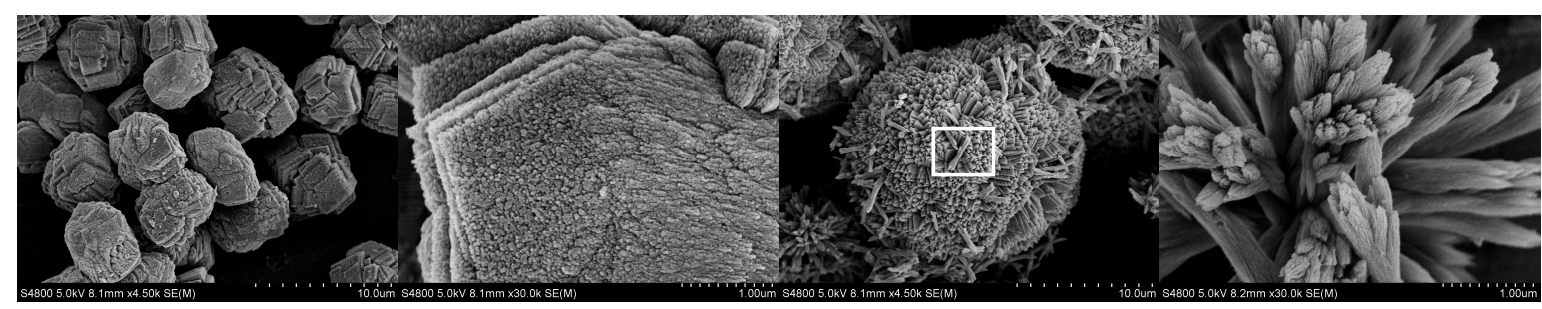

(a)

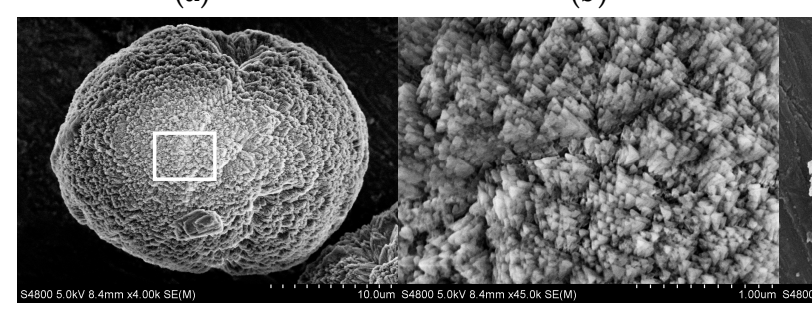

(e)

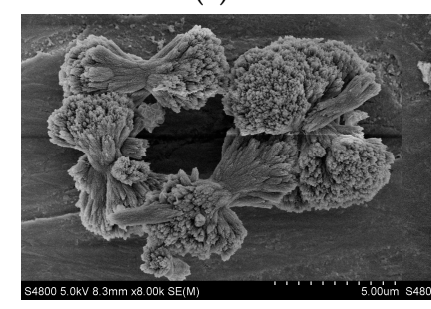

(i)

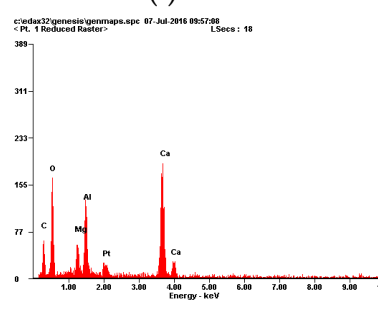

(m)

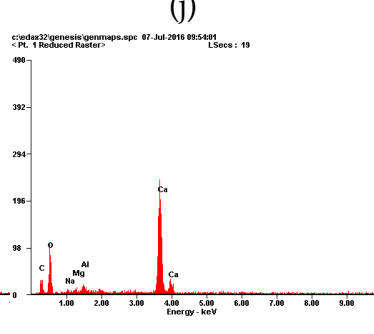

(n) (f)

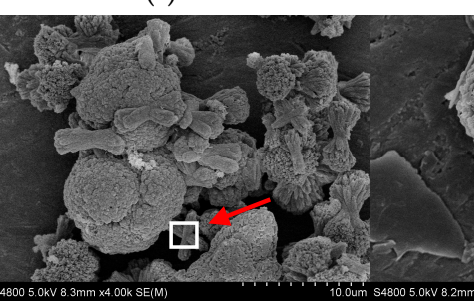

(c)

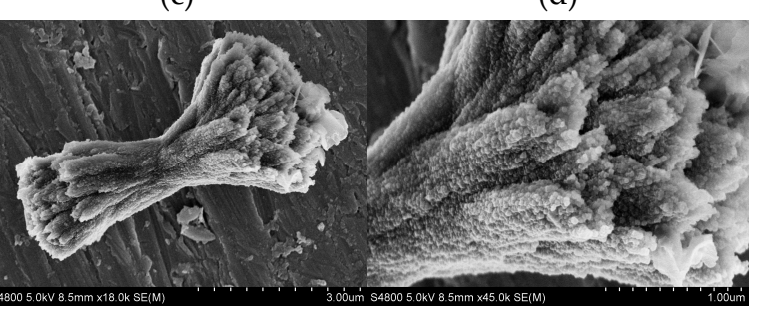

(g)

(h) (d)

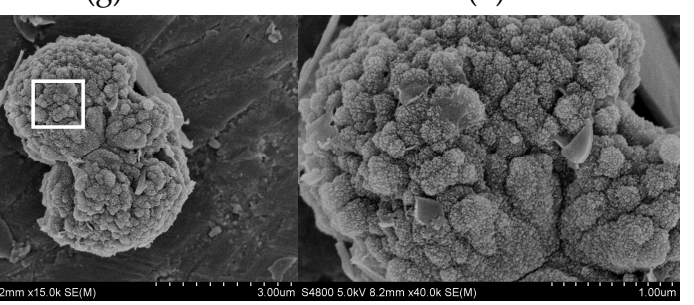

(k)

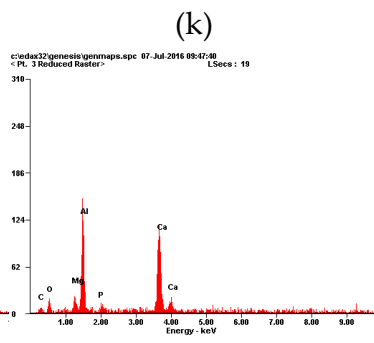

(o)
(1)

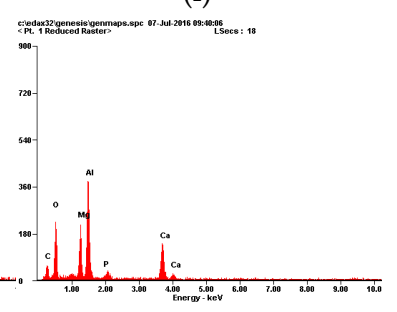

(p)

Figure 8. SEM and EDS images of the minerals in the control group and experimental group at $15 \% \mathrm{NaCl}$ and different $\mathrm{Mg} / \mathrm{Ca}$ molar ratios $\left(\mathrm{Mg}^{2+}\right.$ from $\mathrm{MgCl}_{2} \cdot 6 \mathrm{H}_{2} \mathrm{O}$ ) after 15 days of cultivation. (a), (b) $\mathrm{Mg} / \mathrm{Ca}$ molar ratio of 0 in control group; (c), (d) $\mathrm{Mg} / \mathrm{Ca}$ molar ratio of 2 in control group; (e), (f) $\mathrm{Mg} / \mathrm{Ca}$ molar ratio of 4 in control group; (g), (h) Mg/Ca molar ratio of 0 in experimental group; (i), (j) $\mathrm{Mg} / \mathrm{Ca}$ molar ratio of 2 in experimental 
group; (k), (l) Mg/Ca molar ratio of 4 in experimental group; (m), (n), (o), (p) EDS analysis by the white square, respectively.

By comparing of the morphology and elemental composition of the minerals between $\mathrm{MgSO}_{4}$ and $\mathrm{MgCl}_{2}$ aqueous solution, it could be known that different sources of $\mathrm{Mg}^{2+}$ could affect the surface micromorphology and the elemental composition of the minerals, and the difference was also showed by the different mineral phases formed in the biomineralization process of LD532 bacteria.

At the same time, the surface of the minerals was not observed bacteria in the SEM images of Figure 7 and Figure 8.

\subsection{Nucleation Sites of Minerals on the EPS of C. israelensis LD532 Bacteria}

In order to determine the nucleation sites of carbonate minerals, $C$. israelensis LD532 bacteria in $\mathrm{MgSO}_{4}$ and $\mathrm{MgCl}_{2}$ aqueous solution were analyzed with HRTEM, respectively. Figure 9a shows the micromorphology of $C$. israelensis LD532 bacteria, indicating that the cell surface was covered with different sizes of particulates. It can be obtained from Figure $9 b$ and $c$ that these particulates have a certain crystal structure from the halo ring and the bright spot shown in the SAED spectrum, and are $\mathrm{NaCl}$ crystals obtained from the EDS analysis. Only minor $\mathrm{Mg}$ and Ca elements are shown in the surface of $C$. israelensis LD532 bacteria, indicating that EPS was maybe the nucleation sites of these carbonate minerals in $\mathrm{MgSO}_{4}$ and $\mathrm{MgCl}_{2}$ aqueous solution. Figure $9 \mathrm{~d}$ and e shows that there is a large quantity of microcrystals covered on the EPS, but Figure 9f shows that these microcrystals are mainly composed of $\mathrm{Na}$ and $\mathrm{Cl}$ elements, only minor $\mathrm{Mg}$ and $\mathrm{Ca}$ elements, and therefore the minerals on the EPS were mainly $\mathrm{NaCl}$, maybe there was also less carbonate minerals.

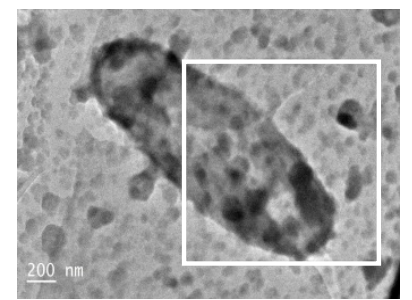

(a)

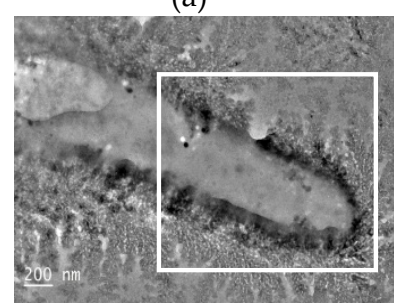

(d)

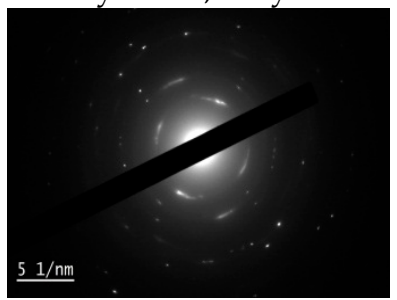

(b)

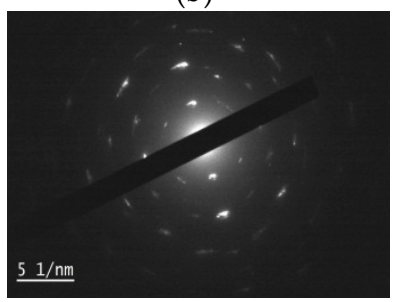

(e)

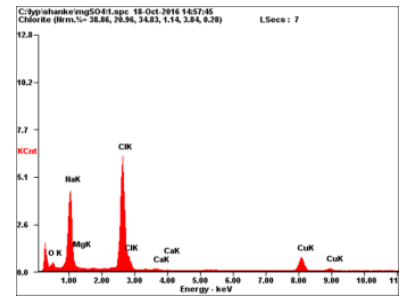

(c)

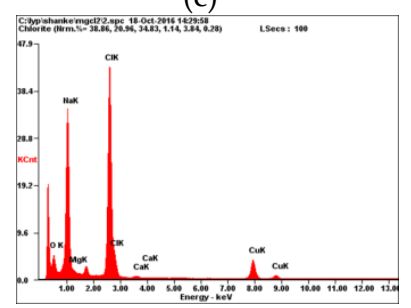

(f)

Figure 9. HRTEM, SADE, EDS analysis LD532 bacteria cells. (a) HRTEM analysis in experimental group of $\mathrm{Mg} / \mathrm{Ca}=2\left(\mathrm{Mg}^{2+}\right.$ from $\left.\mathrm{MgSO}_{4} \cdot 7 \mathrm{H}_{2} \mathrm{O}\right)$; (b) SADE analysis of the bigger inclusions near the cell walls by the white square; (c) EDS analysis by the white square; (d) HRTEM analysis in experimental group of $\mathrm{Mg} / \mathrm{Ca}=2\left(\mathrm{Mg}^{2+}\right.$ from $\mathrm{MgCl}_{2} \cdot 6 \mathrm{H}_{2} \mathrm{O}$ ); (e) SADE analysis of the bigger inclusions near the cell walls by the white square; (f) EDS analysis by the white square.

To further determine the nucleation sites of carbonate minerals, the ultra-thin slices of $C$. israelensis LD532 bacteria in $\mathrm{MgSO}_{4}$ and $\mathrm{MgCl}_{2}$ aqueous solution were prepared and observed by TEM. The results are shown in Figure 10. Figure 10a - c show the images of the ultra-thin slices of $C$. israelensis LD532 bacteria in $\mathrm{MgSO}_{4}$ solution and Figure $10 \mathrm{~d}-\mathrm{f}$ show those in $\mathrm{MgCl}_{2}$ solution. It could be obtained from Figure 10 that minerals in a size of dozens of nanometers were formed in the EPS and cellular insides (marked with yellow arrows), indicating that carbonate minerals could be formed both extracellular and intracellular. These minerals were determined as carbonates due to the fact that $\mathrm{NaCl}$ crystals could not be formed in the cellular interior of halophilic bacteria, and $\mathrm{NaCl}$ had been washed away in the preparation of ultra-thin slices. From the above results, it could be obtained that the nucleation sites of carbonates minerals were located on the EPS and the membrane of intracellular vesicles of $C$. israelensis LD532 bacteria whether in $\mathrm{MgSO}_{4}$ or $\mathrm{MgCl}_{2}$ aqueous solution. 


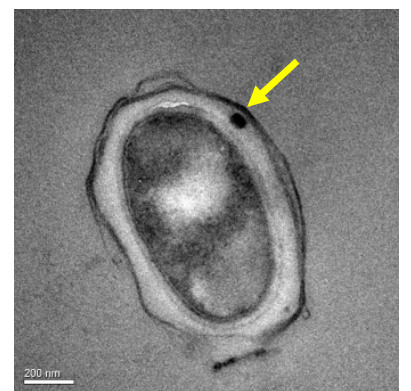

(a)

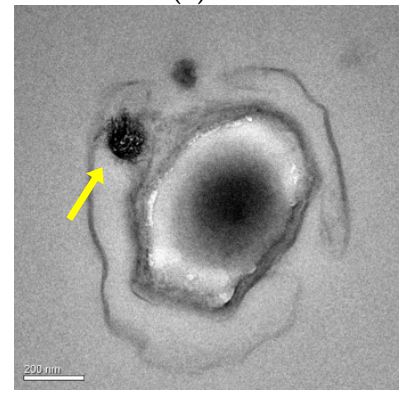

(d)

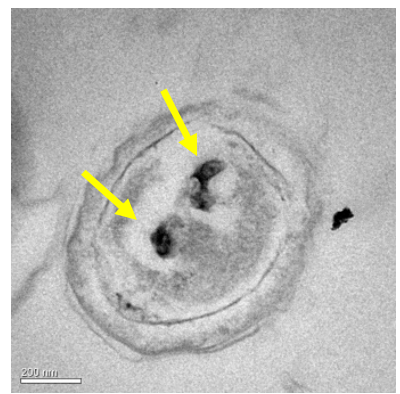

(b)

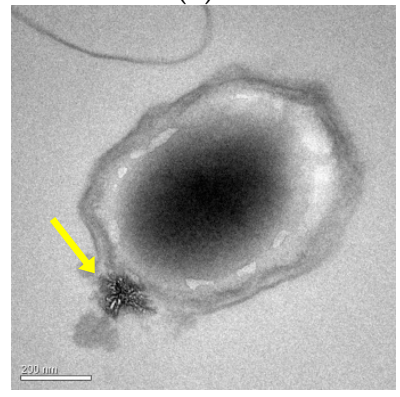

(e)

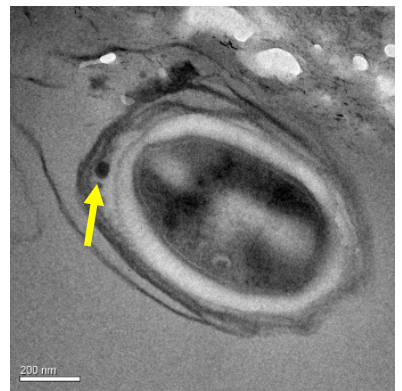

(c)

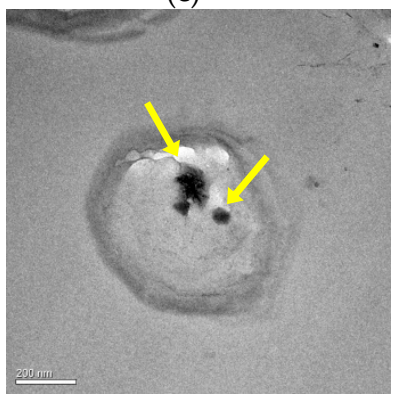

(f)

Figure 10. TEM images of ultrathin cell slices of LD532 bacteria cells in experiment groups after 30 days. (a), (b) and (c) cells in the experimental group with $\mathrm{Mg} / \mathrm{Ca}=2\left(\mathrm{Mg}^{2+}\right.$ from $\left.\mathrm{MgSO}_{4} \cdot 7 \mathrm{H}_{2} \mathrm{O}\right)$; (d), (e) and (f) cells in the experiment group with $\mathrm{Mg} / \mathrm{Ca}=2\left(\mathrm{Mg}^{2+}\right.$ from $\left.\mathrm{MgCl}_{2} \cdot 6 \mathrm{H}_{2} \mathrm{O}\right)$.

\section{Discussion}

\subsection{The biological activity of bacteria affects biomineralization}

Different types of microorganisms can release enormous CA and urease via metabolism, which can change the $\mathrm{pH}$ values in appropriate surroundings [39]. The activity of CA and urease has been found in a wide range of microorganisms and plants [40]. Carbonic anhydrase and urease produced by bacterial metabolic activity have also played an extremely important role in the biomineralization process $[18,19,41]$ due to the fact that they can increase the $\mathrm{pH}$ values in the culture medium to provide a prerequisite for the precipitation of minerals. In this work, CA and urease secreted by $C$. israelensis LD532 bacteria was also found. CA is a ubiquitous metalloenzyme existed in organism which can catalyze the reversible hydration reaction of $\mathrm{CO}_{2}[18]$. CA can eliminate the dynamic obstacles and plays an important catalytic role to promote the inorganic carbon conversion reaction [42]. The conversion between $\mathrm{CO}_{2}$ and $\mathrm{HCO}_{3}$ can be catalyzed by this enzyme and the conversion formula is as follows:

$$
\mathrm{CO}_{2}+\mathrm{H}_{2} \mathrm{O} \leftrightarrow \mathrm{HCO}_{3}^{-}+\mathrm{H}^{+}
$$

The inorganic carbon was existed in the form of carbon dioxide in the acidic solution, but in the form of bicarbonate and carbonate in alkaline conditions. What was more important, there was higher CA activity in alkaline solution ( $\mathrm{pH} 8.8$ or so) as shown in Figure $3 \mathrm{~b}$ and $\mathrm{c}$, indicating that more and more bicarbonate could be released to facilitate the following chemical reaction:

$$
\mathrm{Ca}^{2+}+2 \mathrm{HCO}_{3}^{-} \rightarrow \mathrm{CaCO}_{3} \downarrow+\mathrm{H}_{2} \mathrm{O}+\mathrm{CO}_{2} \uparrow
$$

CA plays an important role in the biomineralization of carbonate. CA is widely distributed and participated in the conversion processes from $\mathrm{CO}_{2}$ to $\mathrm{HCO}_{3}$, acid and ion transport, cellular $\mathrm{pH}$ regulation in calcification and biomineralization [41]. The CA enzyme catalyzes the reversible hydration of $\mathrm{CO}_{2}$ to bicarbonate, which can better understand its possible relation to carbonate precipitation induced by H. anticariensis [28]. As well CA promoted the biomineralization of calcium carbonate in this experiment. 
In this study, it has been obtained that urease can be secreted by LD532 bacteria in the physiological and biochemical identification experiments (Table 1). Urease belonged to the superfamily of amidohydrolase and phosphotriesterase can catalyze the hydrolysis of urea into carbon dioxide and ammonia. The reaction occurs as follows:

$$
\left(\mathrm{NH}_{2}\right)_{2} \mathrm{CO}+\mathrm{H}_{2} \mathrm{O} \rightarrow \mathrm{CO}_{2} \uparrow+2 \mathrm{NH}_{3} \uparrow
$$

More specifically, urea can be hydrolyzed under the catalysis effect of urease to produce ammonia and carbamate, and the carbamate is quickly degraded to release another ammonia and carbonic acid. According to the following equation (4), it could be obtained that urease activity tended to increase the $\mathrm{pH}$ of its environment as it produced ammonia.

$$
\mathrm{NH}_{3}+\mathrm{H}_{2} \mathrm{O} \rightarrow \mathrm{NH}_{4}^{+}+\mathrm{OH}^{-}
$$

The increasing $\mathrm{pH}$ value shown in Figure $3 \mathrm{c}$ was due to the above reason. Carbonic acid produced could be converted to $\mathrm{HCO}_{3}{ }^{-}$in alkaline conditions under the catalysis effect of CA. Therefore the following chemical reaction (5) occurred in the solution:

$$
\mathrm{Ca}^{2+}+\mathrm{HCO}_{3}^{-}+\mathrm{OH}^{-} \rightarrow \mathrm{CaCO}_{3} \downarrow+\mathrm{H}_{2} \mathrm{O}
$$

Our experimental conclusion has been indicated that the alkaline condition formed in the culture medium is a prerequisite for the biomineralization of calcium carbonate. It was also consistent with the previous results $[4,43]$. According to the above reaction, it could be easily found that the chemical process of calcium carbonate precipitation was mainly in reaction (5), indicating that CA and urease activity had a vastly important role in the process of carbonate precipitation.

4.2. Influence of $\mathrm{Mg}^{2+}$ Source and Concentration and Bacterial Strain on Carbonate Minerals

4.2.1 Mineral phases of Carbonate Minerals

In this study, the minerals of $\mathrm{Mg}$-calcite and monohydrocalcite were produced in the experimental group of $\mathrm{Mg} / \mathrm{Ca}$ molar ratio of 2 in $\mathrm{MgSO}_{4}$ solution, while the mineral was only monohydrocalcite in the control group. The minerals were $\mathrm{Mg}$-calcite and a small quantity of aragonite at the same $\mathrm{Mg} / \mathrm{Ca}$ molar ratio in $\mathrm{MgCl}_{2}$ solution in the experimental group, while the mineral also was only monohydrocalcite in the control group. Many researchers have confirmed that the bacteria can modify the chemical composition of the culture medium and create microenvironments to favor the precipitation of carbonate minerals [20,44]. Mineral phases in these two experimental groups were different (Figure $4 b$ and $5 b$ ), due to the fact that bacteria were in different growth environment, one was $\mathrm{MgSO}_{4}$ solution and the other was $\mathrm{MgCl}_{2}$ solution. It has been reported that $\mathrm{Mg}^{2+}$ can damage the crystal structure of calcite because Ca atom can be replaced by $\mathrm{Mg}$ atom. Therefore (104) diffraction peak of calcite moved to the right as shown in Figure $4 \mathrm{~b}$ and $5 \mathrm{~b}$ and $\mathrm{Mg}$-calcite was formed. $\mathrm{Mg}$-calcite formed in $\mathrm{MgSO}_{4}$ and $\mathrm{MgCl}_{2}$ solution at $\mathrm{Mg} / \mathrm{Ca}$ molar ratio of 2 was based on the above principle. While there was also the other mineral, aragonite, formed in $\mathrm{MgCl}_{2}$ solution, not $\mathrm{MgSO}_{4}$ solution, maybe due to the fact that calcite was dissolved and recrystallized in $\mathrm{MgCl}_{2}$ solution. The formation of ion pairs between $\mathrm{SO}_{4}{ }^{2-}$ and $\mathrm{Mg}^{2+}$ maybe weakened the replacement of $\mathrm{Ca}$ atom by $\mathrm{Mg}$ atom, which did not result in the dissolution and recrystallization of calcite in $\mathrm{MgSO}_{4}$ solution, and therefore there were no aragonite crystals to form. Based on the above analysis, it is shown that the different sources of $\mathrm{Mg}^{2+}$ and LD532 bacteria had played a very important role in the formation of new minerals in the biomineralization process.

\subsubsection{Morphology of Carbonate Minerals}

Combined with the XRD and FTIR analyses, Mg-rich calcite were formed in the experimental group of $\mathrm{Mg} / \mathrm{Ca}$ molar ratio of 2 in $\mathrm{MgCl}_{2}$ solution, while monohydrocalcite were formed in control group. Important differences were observed in the morphology of minerals surface formed between the experimental group and the control group (Figure $8 \mathrm{c}, \mathrm{d}$ and $\mathrm{i}, \mathrm{j}$ ). The organic macromolecules in the organism play an important regulate and control role for the formation of the unique morphology and grading of the minerals in the mineralization process [36]. Organic functional 
group have a certain influence on the morphology of the calcite [45]. In our experimental study, the organic functional groups related to biomineralization, such as $\mathrm{C}-\mathrm{H}$ methylene and $\mathrm{C}-\mathrm{H}$ methyl (Figure 6b), played an important role in changing the morphology of Mg-rich calcite.

The morphology of monohydrocalicite induced by different strains and different conditions was variable. In our research, the morphology of monohydrocalicite induced by $C$. israelensis LD532 bacteria was also different at different growth conditions (Figure 7 and 8). Monohydrocalicite formed in same $\mathrm{MgSO}_{4}$ (Figure $7 \mathrm{c}$ and e) was mainly dumbbell-shaped and the surface is also covered with a large quantity of regular or irregular hedrite dissipative crystals, however, monhydrocalicite formed in same $\mathrm{MgCl}_{2}$ (Figure $8 \mathrm{c}$ and e) was mainly spherulite and elliptical and the surface composed of a large number of fibrous mineral crystals and smaller hedrite dissipative crystals. $\mathrm{Mg}^{2+}$ plays a very important role in the formation process of monohydrocalcite. Many researchers have reported that $\mathrm{Mg}$ is ubiquitous in the formation of monohydrocalcite in laboratory and natural environments $[46,47]$ and the prerequisite is high content of $\mathrm{Mg}$ in the culture medium [48]. It is clear that the difference in mineral morphology is caused by different sources of $\mathrm{Mg}^{2+}$ duo to the bacteria do not exist and with the same other conditions during the process of biomineralization. The morphology of calite and monohydrocalicite induced by $\mathrm{C}$. israelensis LD532 bacteria was also different at the same $\mathrm{Mg} / \mathrm{Ca}$ molar ratio and sources of $\mathrm{Mg}^{2+}$ in experimental groups, indicating that the biological activity of bacteria can alter the morphology of the mineral surface.

In this study, it was concluded that the surface morphology of the minerals induced by $C$. israelensis LD532 bacteria were changed and the new mineral phase were increased during the process of biomineralization, the $\mathrm{Mg} / \mathrm{Ca}$ ratios and the source of $\mathrm{Mg}^{2+}$ in the solution not only controlled the composition of the minerals, but also controlled the crystal morphology.

\subsection{The Formation of Aragonite in the Presence of C. israelensis LD532 Bacteria}

The combination of XRD (Figure 5b) and SEM (Figure 8j) results shows that the aragonite was produced when the $\mathrm{Mg} / \mathrm{Ca}$ molar ratio is 2 in the experimental group of $\mathrm{MgCl}_{2}$ solution, while aragonite has not been produced in the control group. The result of EDS shows that the elemental composition of aragonite includes $\mathrm{Al}, \mathrm{Ca}, \mathrm{C}, \mathrm{O}, \mathrm{Mg}$, and $\mathrm{P}$ (Figure 8o). $\mathrm{Al}$ came from the upholder under the sample, $\mathrm{Mg}$ is derived from the culture medium, and $\mathrm{P}$ may be derived from LD532 bacteria. The shape of the aragonite formed in this study was consistent with cross-shaped aragonite observed by the polarized microscope [49]. Researchers have reported that $\mathrm{Mg}^{2+} \mathrm{can}$ hardly be detected in non-biogenic aragonite minerals [50], which are due to the fact that $\mathrm{Mg}^{2+}$ not enter the orthorhombic aragonite lattice, however, many of the aragonite minerals formed by biological genesis contains $\mathrm{Mg}^{2+}$. In this study, the composition elements of the aragonite contained $\mathrm{Mg}^{2+}$ using EDS observation, indicating that $\mathrm{Mg}^{2+}$ may be combined with bacteria to make more $\mathrm{Mg}^{2+}$ into the bio-amorphous calcium carbonate, in other words, C. israelensis LD532 bacteria have an important control effect with respect to $\mathrm{Mg}^{2+}$ content in aragonite.

4.4. Nucleation Sites of Minerals on the EPS of LD532 Bacteria

Bacteria can change their ambient environments [25] and provide nucleation sites by adsorbing $\mathrm{Ca}^{2+}, \mathrm{Mg}^{2+}$ and other metallic cations onto EPS, membranes and walls [21,51] in the formation process of minerals. EPS produced by bacteria not only plays a vital role in changes of the overall ionic charges but also serves as a nucleation site in the process of calcification [41]. It can be obtained from Figure 10 that the intracellular and extracellular biomineralization can occur in LD532 bacteria, indicating the nucleation sites were on the EPS and the membrane of intracellular vesicles. Braissant et al. [20] have stated that bacterium can serve as a nucleus for carbonate mineral precipitation by adsorbing cations around EPS. The formation and structures of carbonate crystals induced by methanogenic archaea are controlled by the cell well and EPS [52]. EPS plays an important role in the complex process of bacterial adhesion to minerals [53]. Meanwhile, our experimental results were consistent with the above conclusions. EPS are mostly composed of polysaccharides (exopolysaccharides) and proteins, but also include other macro-molecules such as DNA, lipids and humic substances. In this study, $\mathrm{pH}$ values were beyond 7.0 from the start of cultivation and increased with the incubation time as shown in Figure $3 c$, indicating that 
biomacromolecules such as proteins and DNA were negatively charged in alkaline environment. Therefore, the positively charged $\mathrm{Ca}^{2+}$ and $\mathrm{Mg}^{2+}$ could be absorbed on these negatively charged biomacromolecules on the EPS and nucleation was occurred subsequently. The presence of $\mathrm{P}$ in Figure $7 \mathrm{o}$ showed that the mineral contained $\mathrm{P}$ element, indicating that there was a close relation between the bacterially induced mineral and DNA due to the fact that there were too many phosphate groups in DNA molecules. Therefore it could be inferred from Figure 10 and Figure 7o that the nucleation of calcium carbonate might occur on the DNA located in the EPS. There have been many great reports that the nucleation sites are located on the EPS for the bacterially induced minerals.

It had been found that no bacteria were on the surface of minerals shown in Figure 7 and 8 , which was due to the fact that $C$. israelensis LD532 bacteria were destroyed and lysed when washing with distilled water in the process of sample preparation for SEM. For the halophilic bacteria, $\mathrm{Na}^{+}$ has an important role in maintaining the structure and function of cell membrane and cell wall [54]. $\mathrm{Na}^{+}$on the cytoderm of halophilic bacteria could not only prevent cytoderm from lysing but also protect their negative charged proteins from being damaged. When $\mathrm{Na}^{+}$were insufficient or diluted in the solution, the cytoderm would lyse due to the change of osmotic pressure and the negative charged proteins would lose their activity, and therefore halophilic bacteria could not live without certain concentration of $\mathrm{NaCl}$. Based on the above analysis, it is can explain why there is no bacterial survival in SEM images.

Through studying the formation process of carbonate minerals at different $\mathrm{Mg} / \mathrm{Ca}$ molar ratios and exploring the mechanism of bacterially-induced biomineralization, it was helpful to explain their role in the ancient biogeochemical cycle and reconstruct the paleoenvironment in geological history, also helpful to explain the origin of carbonate rocks in ancient sedimentary environment, and it was of great significance to study the chemical evolution and early life evolution of paleoceanography in the history of the earth.

\section{Conclusion}

In order to study the effect of microbes, mainly halophiles, on the formation of mineral deposits, C. israelensis LD532 isolated from Yinjiashan Saltern in China was used to investigate the biomineralization process of the carbonate minerals at different $\mathrm{Mg} / \mathrm{Ca}$ molar ratios and different sources of $\mathrm{Mg}^{2+}$. CA and urease activity played an extremely important role in the process of biomineralization. The intracellular and extracellular biomineralization could occur in LD532 bacteria and the nucleation sites were on the EPS and the membrane of intracellular vesicles. There were significant differences between the minerals formed in $\mathrm{MgSO}_{4}$ and those formed in $\mathrm{MgCl}_{2}$ solution, such as surface morphology and phase, indicating that different sources of $\mathrm{Mg}^{2+}$ could affect the physiological and biochemical activities of microorganisms and then affect the mineral deposition.

Acknowledgements: This work was supported by the National Natural Science Foundation of China (41372108, U1663201), Open Fund of the Key Laboratory of Marine Geology and Environment, Chinese Academy of Sciences (No. MGE2016KG10), the Specialized Research Fund for the Doctoral Program of Higher Education (20133718130001), and supported by SDUST Research Fund (2015TDJH101), Shandong Provincial Key Laboratory of Depositional Mineralization and Sedimentary Minerals (DMSM201412), Shandong Province Natural Science Foundation (ZR2013DQ005, ZR2014DM005), the China Postdoctoral Science Foundation founded project (2013M540560, 2014T70659, 2016M600548), Qingdao Postdoctoral Applied Research Project (2015199).

Author Contributions: Zuozhen Han conceived and designed the experiments; Dan $\mathrm{Li}$ and Peiyuan $\mathrm{Li}$ performed the experiments; Zuozhen Han and Huaxiao Yan analyzed all the empirical date; Dan Li and Huaxiao Yan wrote the paper. All authors read and approved the manuscript.

Conflicts of Interest: The authors declare no conflict of interest.

\section{References}

1. Spötl, C.; Fairchild, I.J.; Tooth, A.F. Cave air control on dripwater geochemistry, Obir Caves (Austria): Implications for speleothem deposition in dynamically ventilated caves[J]. Geochimica et Cosmochimica Acta 2005, 69, 2451-2468.

2. Morita, R.Y. Calcite precipitation by marine bacteria. Geomicrobiology Journal 1980, 2, 63-82. 
3. Ferris, F.G.; Fyfe, W.S.; Beveridge, T.J. Bacteria as nucleation sites for authigenic minerals in a metal-contaminated lake sediment. Chemical Geology 1987, 63, 225-232.

4. Castanier, S.; Le M'etayer-Levrel, G.; Perthuisot, J.P. Ca-carbonate precipitation and limestone genesis-the microbiologist point of view. Sediment Geol 1999, 126, 9-23.

5. Rivadeneyra, M.A.; Delgado, G.; Ramos-Cormenzana, A.; Delgado, R. Biomineralization of carbonates by Halomonas eurihalina in solid and liquid media with different salinities: crystal formation sequence. Res Microbiol 1998, 149, 277-287.

6. Rivadeneyra, M.A.; Párraga, J.; Delgado, R.; Ramos-Cormenzana, A.; Delgado, G. Biomineralization of carbonates by Halobacillus trueperi in solid and liquid media with different salinities. FEMS Microbiol Ecol 2004, 48, 39-46.

7. Rivadeneyra, M.A.; Martín-Algarra, A.; Sánchez-Navas, A.; Martín-Ramos, D. Carbonate and phosphate precipitation by Chromohalobacter marismortui. Geomicrobiol J 2006, 23, 89-101.

8. Rivadeneyra, M.A.; Martín-Algarra, A.; Sánchez-Román, M.; Sánchez-Navas, A.; Martín-Ramos, J.D. Amorphous Ca-phosphate precursors for Ca-carbonate biominerals mediated by Chromohalobacter marismortui. ISME J 2010, 4, 922-932.

9. Van Lith, Y.; Warthmann, R.; Vasconcelos, C.; Mckenzie, J.A. Sulphate-reducing bacteria induce low-temperature Ca-dolomite and high Mg-calcite formation. Geobiology 2003, 1, 71-79.

10. Sánchez-Román, M.; Rivadeneyra, M.A.; Vasconcelos, C.; McKenzie, J.A. Biomineralization of carbonate and phosphate by moderately halophilic bacteria. FEMS Microbiol Ecol 2007, 61, 273-284.

11. Ehrlich, H.L. Geomicrobiology 4th Ed (Revised and Expanded). New York: Marcel Dekker Inc 2002.

12. Kranz, S.A.; Wolf-Gladrow, D.; Nehrke, G.; Langer, G.; Rost, B. Calcium carbonate precipitation induced by the growth of the marine cyanobacteria Trichodesmium [J]. Limnology and Oceanography 2010, 55, 25632569.

13. Braissant, O.; Decho, A.W.; Dupraz, C.; Glunk, C.; Przekop, K.M.; Visscher, P.T. Exopolymeric substances of sulfate-reducing bacteria: Interactions with calcium at alkaline $\mathrm{pH}$ and implication for formation of carbonate minerals. Gebiology 2007, 5, 401-411.

14. Ercole, C.; Cacchio, P.; Botta, A.L.; Centi, V.; Lepidi, A. Bacterially induced mineralization of calcium carbonate: the role of exopolysaccharides and capsular polysaccharides [J]. Microscopy and Microanalysis 2007, 13, 42-50.

15. Boquet, E.; Boronat, A.; Ramos-Cormenzana, A. Production of calcite (calcium carbonate) crystals by soil bacteria is a general phenomenon. Nature (Lond) 1973, 246, 527-529.

16. Lowenstam, H.A.; Weiner, S. (eds) On Biomineralization. Oxford University Press, Oxford 1989.

17. Bachmeier, K.L.; Williams, A.E.; Warmington, J.R.; Bang, S.S. Urease activity in microbiologically-induced calcite Precipitation. Journal of Biotechnology 2002, 93, 171-181.

18. Dhami, N.K.; Mukherjee, A.; Reddy, M.S. Micrographical minerological and nano-mechanical characterisation of microbial carbonates from urease and carbonic anhydrase producing bacteria. Ecological Engineering 2016, 94, 443-454.

19. Lian, B.; Hu, Q.N.; Chen, J.; Ji, J.F.; Teng, H.H. Carbonate biomineralization induced by soil bacterium Bacillus megaterium. Geochimica and Cosmochimica Acta 2006, 70, 5522-5535.

20. Braissant, O.; Cailleau, G.; Dupraz, C.; Verrecchia, E.P. Bacterially induced mineralization of calcium carbonate in terrestrial environment: the role of exopolysaccharides and amino-acids. J Sediment Res 2003, 73, 485-490.

21. Van Lith, Y.; Warthmann, R.; Vasconcelos, C.; Mckenzie, J.A. Microbial fossilization in carbonate sediments: a result of the bacterial surface involvement in dolomite precipitation. Sedimentology 2003, 50, 237-245.

22. Rivadeneyra, M.A.; Delgado, R.; Parraga, J.; Ramos-Cormenzana, A.; Delgado, G. Precipitation of Minerals by 22 Species of Moderately Halophilic Bacteria in Artificial Marine Salts Media: Influence of Salt Concentration. Folia Microbiol 2006, 51, 445-453.

23. Taylor, S.R.; Mclennan, S.M. The Continental Crust. Its Evolution and Composition [M]. Oxford: Blackwell Science 1985.

24. Stanley, S.M.; Ries, J.B.; Hardie, L.A. Low-magnesium calcite produced by coralline algae in seawater of Late Cretaceous composition. P Natl Acad Sci USA 2002, 99, 15323-15326.

25. Sánchez-Román, M.; Romanek, C.S.; Fernández-Remolar, D.C.; Sánchez-Navas, A.; McKenzie, J.A.; Pibernat, R.A.; Vasconcelos, C. Aerobic biomineralization of Mg-rich carbonates: Implications for natural environments. Chemical Geology 2011, 281, 143-150. 
26. Rodriguez-Blanco, J.D.; Shaw, S.; Bots, P.; Roncal-Herrero, T.; Benning, L.G. The role of Mg in the crystallization of monohydrocalcite. Geochimica et Cosmochimica Acta 2014, 127, 204-220.

27. Ventosa, A.; Gutierrez, M.C.; Garcia, M.T.; Ruiz-Berraquero, F. Classification of "Chomobacterium marismortui" in a New Genus, Chromohalobacter gen.nov., as Chromohalobacter marismortui comb. nov., nom.rev. Inter J System Bacteriol 1989, 39, 382-385.

28. Rivadeneyra, A.; Rivadeneyra, M.A.; Escamilla, C.V.; Algarra, A.M.; Navas, A.S.; Martín-Ramos, J.D. The influence of Salt Concentration on the Precipitation of Magnesium Calcite and Calcium Dolomite by Halomonas Anticariensis. Expert Opin Environ Biol 2016.

29. Deng, S.C.; Dong, H.L.; Lv, G.; Jiang, H.C.; Yu, B.S.; Bishop, M.E. Microbial dolomite precipitation using sulfate reducing and halophilic bacteria: Results from Qinghai Lake, Tibetan Plateau, NW China. Chemical Geology 2010, 278, 151-159.

30. Babavalian, H.; Amoozegar, M.A.; Pourbabaee, A.A.; Moghaddam, M.M.; Shakeri, F. Isolation and identification of moderately halophilic bacteria producing hydrolytic enzymes from the largest hypersaline playa in Iran. Microbiology 2013, 82, 466-474.

31. Kim, C.S.; Lee, C.H.; Shin, J.S.; Chung, Y.S.; Hyung, N.I. A simple and rapid method for isolation of high quality genomic DNA from fruit trees and conifers using PVP. Nucl Acids Res 1997, 25, 1085-1086.

32. Madhaiyan, M.; Poonguzhali, S.; Kwon, S.W.; Sa, T.M. Methylobacterium phyllosphaerae sp. nov., a pink-pigmented, facultative methylotroph from rice. Int J Syst Evol Microbiol 2009, 59, $22-27$.

33. Weisburg, W.G.; Barns, S.M.; Pelletier, D.A.; Lane, D.J. $16 S$ ribosomal DNA amplification for phylogenetic study. J Bacteriol 1991, 2, 697-703.

34. Smith, K.S.; Ferry, J.G. A plant-type ( $\beta$-class) carbonic anhydrase in the thermophilic methanoarchaeon Methanobacterium thermoautotrophicum. J Bacteriol 1999, 181, 6247-6253.

35. Goldsmith, J.R.; Graf, D.L.; Heard, H.C. Lattice constants of the calcium-magnesium carbonates. Am Mineral 1961, 46, 453-457.

36. Arvidson, R.S.; Mackenzie, F.T. The dolomite problem: Control of precipitation kinetics by temperature and saturation state. Am J Sci 1999, 299, 257-288.

37. Guo, C.; Liu, H.Z.; Wang, J.; Chen, J.Y. Conformational structure of triblock copolymers by FT-Raman and FTIR spectroscopy. J. Colloid Interface Sci 1999, 209, 368-373.

38. Su, Y.L.; Liu, H.Z.; Guo, C.; Wang, J. Association behavior of PEO-PPO-PEO block copolymers in water or organic solvent observed by FTIR spectroscopy. Mol. Simul 2003, 29, 803-808.

39. Mobley, H.L.; Island, M.D.; Hausinger, R.P. Molecular biology of microbial ureases. Microbiol Rev 1995, 59, 451-480.

40. Ciurli, S.; Marzadori, C.; Benini, S.; Deiana, S.; Gessa, C. Urease from the soil bacterium Bacillus pasteurii: immobilization on Ca-polygalacturonate. Soil Biol Biochem 1996, 28, 811-817.

41. Achal, V.; Pan, Xiangliang. Characterization of urease and carbonic anhydrase producing bacteria and their role in calcite precipitation. Current Microbiology 2011, 62, 894-902.

42. Han, Z.Z.; Zhao, Y.Y.; Yan, H.X.; Zhao, H.; Han, M.; Sun, B.; Meng, R.R.; Zhuang, D.X.; Li, D.; Gao, W.J.; Du, S.Y.; Wang, X.A.; Fan K.X.; Hu W.Y.; Zhang, M.X. The Characterization of Intracellular and Extracellular Biomineralization Induced by Synechocystis sp. PCC6803 Cultured under Low Mg/Ca Ratios Conditions. Geomicrobiology 2016, 1-12.

43. De Muynck, W.; De Belie, N.; Verstraete, W. Microbial carbonate precipitation in construction materials: A review. Ecol Eng 2010, 36, 118-136.

44. Cailleau, G.; Braissant, O.; Dupraz, C.; Aragno, M.; Verrecchia, E.P. Biologically induced accumulation of $\mathrm{CaCO}_{3}$ in orthox soils of Biga. Ivory Coast Catena 2005, 59, 1-17.

45. Wang, Y.Y.; Yao, Q.Z.; Zhou, G.T.; Fu, S.Q. Formation of elongated calcite mesocrystals and implication for biomineralization. Chemical Geology, 2013, 360-361, 126-133.

46. Fukushi, K.; Munemoto, T.; Sakai, M.; Yagi, S. Monohydrocalcite: a promising remediation material for hazardous anions. Sci. Technol. Adv. Mater 2011, 12, 1-12.

47. Nishiyama, R.; Munemoto, T.; Fukushi, K. Formation condition of monohydrocalcite from $\mathrm{CaCl}_{2}-\mathrm{MgCl}_{2}-$ $\mathrm{Na}_{2} \mathrm{CO}_{3}$ solutions. Geochimica et Cosmochimica Acta 2013, 100, 217-231.

48. Kimura, T.; Koga, N. Monohydrocalcite in comparisonwith hydrated amorphous calcium carbonate: precipitation condition and thermal behavior. Cryst. Growth Des 2011, 11, 3877-3884.

49. Han, Z.Z.; Meng, R.R.; Yan, H.X.; Zhao, H.; Han, M.; Zhao, Y.Y.; Sun, B.; Sun, Y.B.; Wang, J.; Zhuang, D.X.; Li, W.J.; Lu, L.X. Calcium carbonate precipitation by Synechocystis sp. PCC6803 at different Mg/Ca molar 
ratios under the laboratory condition. Carbonates Evaporites 2016, 1-15. DOI: 10.1007/s13146-016-0322-5.

50. Porter, S.M. Seawater chemistry and early carbonates biomineralization [J]. Science 2007, 316, 1302.

51. Bontognali, T.R.R.; Vasconcelos, C.; Warthmann, R.J.; Dupraz, C.; Bernasconi, S.M.; McKenzie, J.A. Microbes produce nanobacteria-like structures, avoiding entombment. Geology 2008, 36, 663-666.

52. Kenward, P.A.; Goldstein, R.H.; Gonzalez, L.A.; Roberts, J.A. Precipitation of low-temperature dolomite from an anaerobic microbial consortium: the role of methanogenic Archaea. Geobiology 2009, 7, 556-565.

53. Li, Q.; Wang, Q.F.; Zhu, J.Y.; Zhou, S.; Gan, M.; Jiang H.; Sand, W.G. Effect of Extracellular Polymeric Substances on Surface Properties and Attachment Behavior of Acidithiobacillus ferrooxidans. Minerals 2016, 6, 1-11.DOI: 10.3390/min6040100.

54. Von Weymarn, N.; Nyyssölä, A.; Reinikainen, T.; Leisola, M.; Ojamo, H. Improved osmotolerance of recombinant Escherichia coli by de novo glycine betaine biosynthesis[J]. Applied microbiology and biotechnology 2001, 55, 214-218.

(C) 2017 by the authors. Licensee Preprints, Basel, Switzerland. This article is an open access article distributed under the terms and conditions of the Creative Commons by Attribution (CC-BY) license (http://creativecommons.org/licenses/by/4.0/). 